\title{
AfTer 2000 Stože LandSlide: Part I - Development IN LANDSLIDE ReSEarCh IN SLOVENIA
}

\author{
PO ZEMELJSKEM PLAZU STOŽE LETA 2000: DEL I - RAZVOJ RAZISKOVANJA \\ ZEMELJSKIH PLAZOV V SLOVENIJI \\ Matjaž Mikoš ${ }^{1}$ \\ ${ }^{1}$ Raziskovalni inštitut za geo in hidro tveganja (RIGHT), Fakulteta za gradbeništvo in geodezijo, \\ Univerza v Ljubljani, Jamova c. 2, 1000 Ljubljana
}

\begin{abstract}
The 2000 Stože Landslide with the consecutive wet debris flow with a volume close to 1 million $\mathrm{m}^{3}$ that hit the village of Log pod Mangartom in November 2000 had many consequences. It triggered vast efforts not only for the mitigation of the devastated area but also sparked many studies in several scientific disciplines. Various studies were performed in order to better understand this type of natural hazard and its consequences for the natural and built environment, and for society as a whole. After two decades since the disastrous event in 2000, this paper provides an aggregate survey different studies on this event performed by researchers and engineers, summarising this event's impact on in-depth landslide research in Slovenia. The advancement in this field in Slovenia since 2000 is obvious.
\end{abstract}

Keywords: debris flows, landslides, landslide research, natural disasters, natural risks, Stože landslide

\section{Izvleček}

Zemeljski plaz Stože in za njim mokri drobirski tok s prostornino blizu 1 milijona $\mathrm{m}^{3}$, ki je novembra 2000 prizadel vas Log pod Mangartom, je imel številne posledice. Sprožil je velika prizadevanja ne le za ublažitev opustošenega območja, temveč tudi študije tega primera v različnih znanstvenih disciplinah. Namen različnih opravljenih študij je bil izboljšati razumevanje tovrstnih naravnih nevarnosti in njihovih posledic za naravno in grajeno okolje ter družbo v celoti. Po dveh desetletjih od katastrofalnega dogodka v letu 2000 prispevek podaja pregled različnih študij tega dogodka, ki so jih izvedli raziskovalci in inženirji, ter povzema vpliv tega dogodka na poglobljeno raziskovanje zemeljskih plazov v Republiki Sloveniji. Napredek na področju raziskovanja zemeljskih plazov v Sloveniji po letu 2000 je očiten.

Ključne besede: drobirski tok, naravne nesreče, naravna tveganja, raziskovanje zemeljskih plazov, Stože, zemeljski plazovi

\footnotetext{
${ }^{1}$ Stik / Correspondence: matjaz.mikos@fgg.uni-lj.si

(C) Mikoš M.; Vsebina tega članka se sme uporabljati v skladu s pogoji licence Creative Commons Priznanje avtorstva - Nekomercialno - Deljenje pod enakimi pogoji 4.0 .

(C) Mikoš M.; This is an open-access article distributed under the terms of the Creative Commons Attribution - NonCommercial ShareAlike 4.0 Licence.

https://doi.org/10.15292/acta.hydro.2020.09
} 


\section{Introduction}

On 15 November 2000 a debris landslide with a volume of over 1 million $\mathrm{m}^{3}$ was triggered without any warning on the Stože slope below Mt Mangart $(2,679 \mathrm{~m}$ a.s.1.) in the Julian Alps of NW Slovenia (Fig. 1). While moving on the slope, it turned into a dry debris flow that within minutes hit the main road from Bovec (Slovenia) over Predel Pass (1,156 m a.s.l.) to Tarvis (Italy) and stopped at the confluence of the Mangart Creek and the Predelica Torrent. Less than 35 hours later, just after the midnight on 17 November 2000, the relatively dry deposits of the first debris flow, which in the meantime had been soaked by intense local rainfalls and by the infiltration of inflowing water from the Mangart Creek, slipped and turned into a wet debris flow of volume close to 1 million $\mathrm{m}^{3}$. This debris flow ran along the steep ravine of the Predelica Torrent and hit the village of Log pod Mangartom, claiming 7 casualties and causing significant economic damage in excess of 10 million EUR (Četina et al., 2006).

As the Stože landslide area prior to the catastrophic event in November 2000 had experienced occasional ground shaking after the major earthquake in the Upper Soča Territory on 12 April 1998 (Zupančič et al., 2001), questions arose as to whether a local earthquake had been the cause of the 2000 Stože Landslide and its consecutive debris flows. Ribičič and Vidrih (2001) concluded that occasional local seismic tremors after the major 1998 Soča Earthquake had no direct triggering effect on the 2000 Stože Landslide. After the 2000 Stože Landslide, also two accelerographs were set up in Log pod Mangartom and the nearby Soča village, but no increased seismic activity was recorded in the area any time till May 2001, and the temporary seismic station was removed (Gostinčar, 2001). Therefore, the 2000 Stože Landslide cannot be taken as a quake-triggered event. It was rather a rainfall-triggered two-phases catastrophic event.

It was the largest natural disaster of this kind in the 20th century in Slovenia. In Slovenia and its NW surroundings, landslides of various forms are quite frequent (Jemec Auflič at al., 2017). This paper deals with the question "What lessons have been learned from this natural event?" and less with a detailed description of the event itself, shortly described beforehand. Numerous publications on the event itself and its consequences have been published since November 2000; partially in local and national newspapers and magazines (e.g. Zlodej, 2001), and mainly in journals (Četina et al., 2002; Horvat, 2001; Komac, 2001; Lenart, 2016; Majes, 2001a; Mikoš, 2001; Ribičič, 2001; Majes and Beseničar, 2002; Zorn and Komac, 2002) and at national and international conferences (Brilly et al., 2001; 2002; Fazarinc et al, 2002; Hojnik et al., 2001; Komac and Zorn, 2008; Majes, 2001b; Majes and Petkovšek, 2001; Majes et al., 2001; 2002b,c,d). This immediate response in the scientific and professional community in Slovenia confirmed their interest to investigate and to understand what happened in November 2000 in Log pod Mangartom.
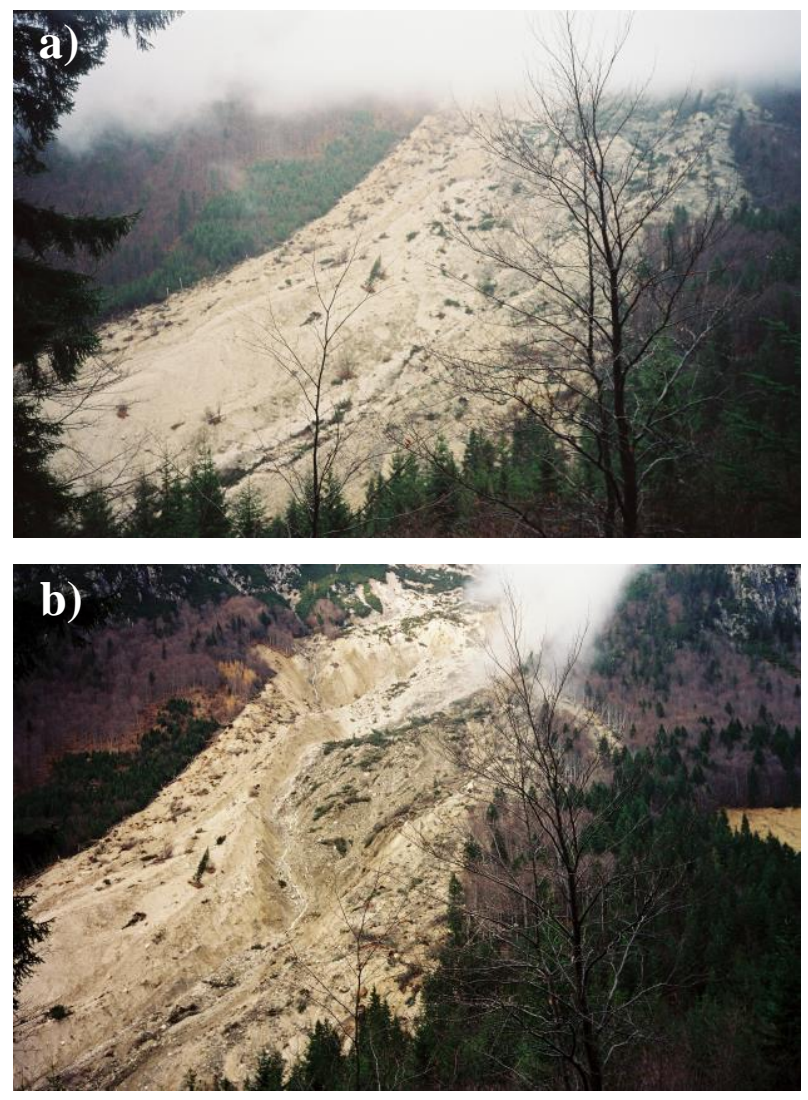

Figure 1: Comparison between the situation on the Stože slope above the Mangart Torrent after: a) the first event of 15 November 2000 (above); b) the second event of 17 November 2000 (below).

Slika 1: Primerjava med razmerami na pobočju Stože nad Mangartskim potokom po: a) prvem dogodku 15. 11. 2000 (zgoraj); b) drugem dogodku 17. 11. 2000 (spodaj). 
This paper reviews the majority of the material published by Slovenian researchers and engineers, i.e. from the technical and engineering point of view, but not from social or economic perspectives, due simply to the focus of the journal Acta Hydrotechnica. This paper will contribute to a general understanding what happened in 2000 , and whether we are prepared for similar natural events in future. A companion paper (Mikoš, submitted) gives a review on the development in landslide risk reduction policy in Slovenia after the 2000 Stože Landslide.

Some other review papers are available about the mitigation of large landslides and debris flows in Slovenia, triggered at the turn of the 20th into 21 th century: among others the Stože, Strug, Macesnik, Slano Blato, and Stogovce landslides, respectively (Zorn and Komac, 2004; Zorn et al., 2006; Majes, 2005; Mikoš and Majes, 2008; 2010: Petkovšek et al., 2011), thus including further information on the remediation of the devastated area in Log pod Mangartom, and control measures in the source area on the Stože slope.

\section{Debris flows as a landslide type}

Debris flows are one of numerous types of landslides (Varnes, 1978; updated by Hungr et al., 2014); compared to slides, slumps, or rock falls, they are rare events in Slovenia - expertise on this type of slope processes was not widespread in Slovenia a few decades ago; even though landslides are quite frequent natural hazards in Slovenia (Mikoš et al., 2004a).

Definitions of debris flows differ; Allaby (2013) in his glossary of geology and earth sciences defined debris flow "as slow-moving, sediment gravity flow composed of large clasts supported and carried by a mud-water mixture."

Hutchinson (1968) introduced debris flows as a form of landslides, and later divided them into channelized and hillslope varieties (Hutchinson, (1988). This corresponds to the debris flow and debris avalanche of Varnes (1978).

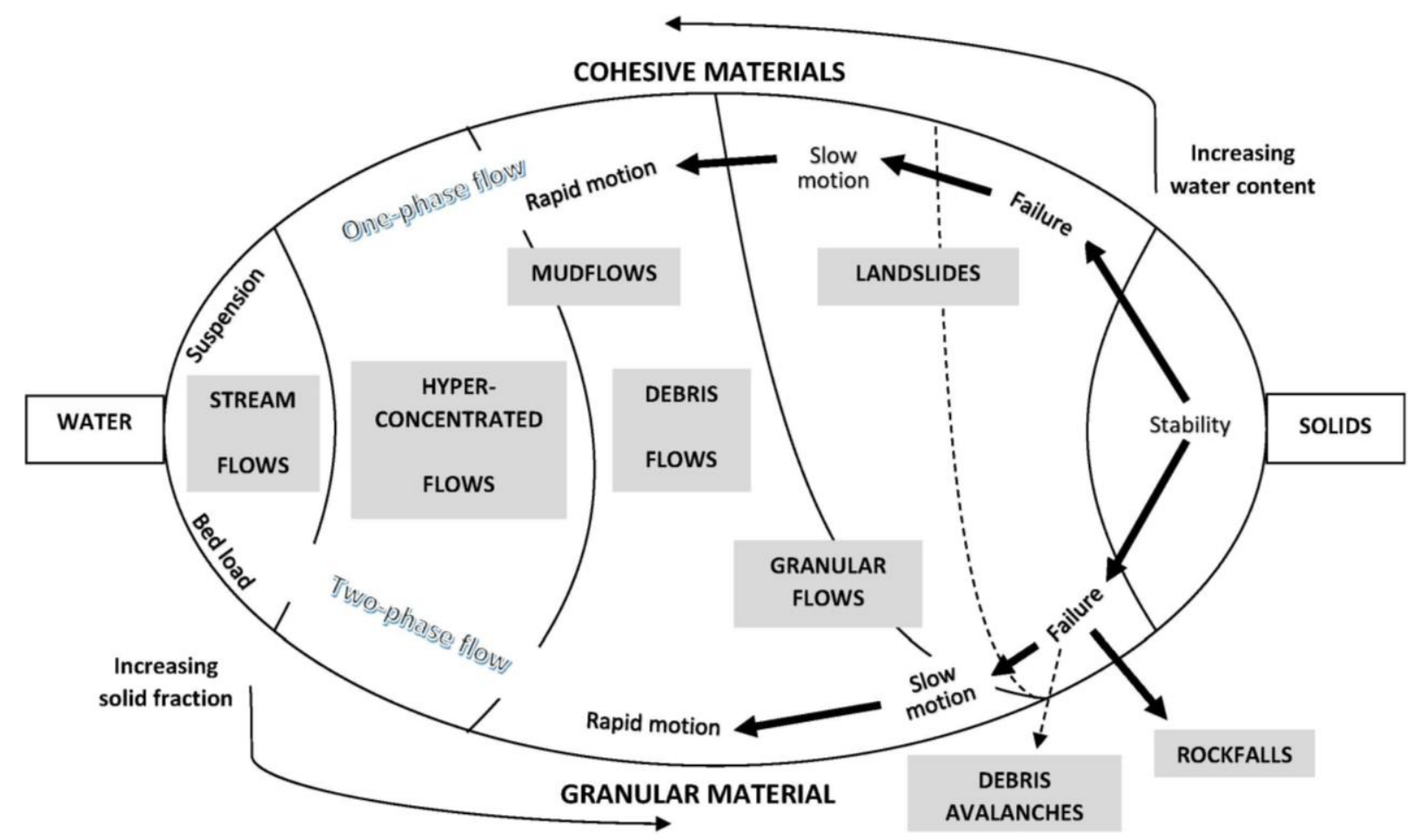

Figure 2: Classification of mass movements on steep slopes as a function of solid fraction and material type (after Menuier, 1991; Coussot and Meunier, 1996).

Slika 2: Klasifikacija masnih premikov na strmih pobočjih v odvisnosti od deleža trdne faze in vrste drobirskega materiala (po Meunier, 1991; Coussot in Meunier, 1996). 


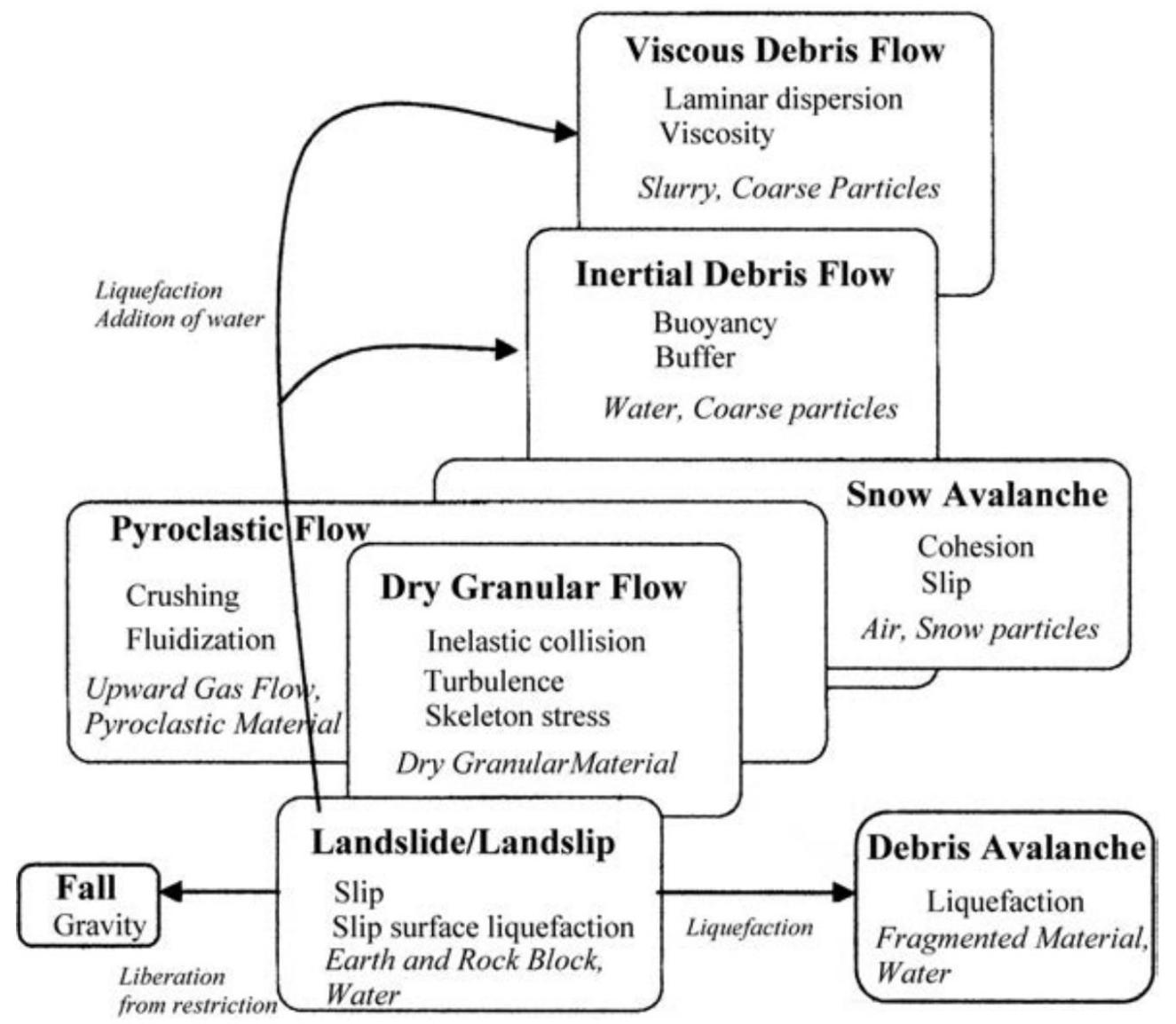

Figure 3: Subaerial mass movements; their mechanical resemblances and differences (after Takahashi, 2014; Fig. 1.1).

Slika 3: Kopenska masna gibanja: njihove mehanske podobnosti in razlike (po Takahashi, 2014; slika 1.1).

Taking up the original definition proposed by Takahashi (1981), debris flows are massive sediment transport phenomena that manifest themselves in mountain streams characterized by a steep slope, where the motion of the granular phase is induced directly by gravity.

The interaction among different mass movements regarding solid fraction and material type was introduced by Menuier (1991) and upgraded by Coussot and Menuier (1996), as shown in Fig. 2. There is a continuous transition from fluvial (torrential) stream flows in steep channels to hyperconcentrated flows and finally to debris flows and mud flows as a type of mass movements.

The International Association for Hydraulic Research (IAHR) and its Section on Fluvial Hydraulics published a series of monographs related to this type of mass movement, namely by the following authors: Takahashi (1991) on debris flows, Wan and Wang (1994) on hyperconcentrated flows, and Coussot (1997) on mudflow rheology and dynamics. An in-depth monograph on debris flows, debris avalanches, and debris floods was edited by Jakob and Hunger (2005)

Armanini et al. (2005) defined debris flow as a motion of widely sorted debris (from a few millimeters to some meters) inside a watery matrix or also in the presence of clayish mud. One of the most evident facts is the floatation of huge boulders on the surface of the debris flow.

The interactions between subaerial mass movements are shown on Fig. 3 as proposed by Takahashi (2014). Viscous and inertial debris flows can be initiated from landslides and/or landslips by liquefaction (addition of water); this is likely to have been the case for the 2000 Stože Landslide. 


\section{Landslide-related terminology issues in Slovenian language}

We have faced such events as was the 2000 Stože Landslide in the past and called them "murasti tok" in Slovene terminology - a term based on German word "die Mure", an equivalent to English term "debris flow". The term "Mura" was adopted from German (Stiny, 1910), and has nothing to do with the Mura River in NE Slovenia. After 2000 Stože Landslide, we reached an agreement to start using only the term "debris flow" (slov. drobirski tok) in all reports on the 2000 event. This might be seen as the start of the in-depth discussion on Slovene terminology addressing mass movements. Immediate papers this topic were written by geographers (Gams, 2001), geologists (Skaberne, 2001; 2002; Ribičič, 2002), and civil engineers (Mikoš, 2001 - based on a previous paper on terms in the field of erosion processes: Mikoš, 2000).

The main problem in Slovene terminology lies in the following facts:

- Geologists do not study (snow) avalanches; thus, they use term sliding (slov. plazenje) for landslides (slov. zemeljski plazovi) - the English translation would be earth slides).

- Geographers use the term avalanche prone areas (slov. plazovito območje) from the Water Act (ZV-1, 2002: ZV-1-NPB8, 2020) for landslide prone areas (slov. plazljivo območje).

- The Water Act (ZV-1, 2002: ZV-1-NPB8, $2020)$ introduced inter alia two terms for risk areas: avalanche risk area (slov. plazovito območje) and landslide risk area (slov. plazljivo območje) - this legislative distinction is still not fully understood and used in geological terminology in Slovenia. An additional possibility for avalanche prone areas and avalanche-related issues would be to use the expression "lavinski", i.e. from the Latin adjective "lavinus".

- Specific problem to be solved in the field of recognising hazard areas are debris flows that can be triggered: i) in torrential channels (channelized debris flows); or ii) on unstable slopes (slope debris flows). The former processes should be covered by the methodology on flood and erosion risk areas, and the latter ones by the one on landslide risk areas

- The problem is that in nature such processes are often spatially and in time inter-connected. An example of such chains in natural hazards is shown on Fig. 4 for a case of a strong continental earthquake.

Therefore, debris flows cannot be "missed out" in relevant methodologies. Partially, the problem lies in the terminology in that the term erosion (slov. erozija) was for decades used in Slovenian terminology also for all mass movements and/or slope processes under exogenic driving forces such as wind, snow, ice, gravity or water (Mikoš, 1995).

Tectonic and volcanic action was not covered in the Slovenian terminology under the broad term of "erosion" as a term applied for any sub-aerial denudation process on the Earth surface. After 2000 Stože Landslide, the term erosion is more and more restricted in Slovenian terminology to the field where it belongs to - i.e. to soil erosion as in English terminology. Other exogenic Earth mass wasting processes that are associated with soil erosion, are covered by the expression mass movements (slov. masni premiki ali masna gibanja) or slope processes (slov. pobočni procesi).

In geographical sciences, Komac and Zorn (2007) summarised important literature of Slovenian geographers in the field of slope processes. In Zorn and Komac (2008) the overview was supplemented by newer works from geographical sciences and works from other disciplines.

It is to be respected that different scientific disciplines are using their own terminology. For more on Slovene terminology in geographical sciences, one is directed to Geographical terminological dictionary (Geografski terminološki slovar, 2013) and in geological sciences to Geological terminological dictionary (Geološki terminološki slovar, 2006). The former defines the term "murasti tok" as an inappropriate term, to be replaced by "drobirski tok" (Eng. debris flow), and the latter also defines it as an inappropriate term, but to be replaced by "blatni tok" (Eng. mud flow). 


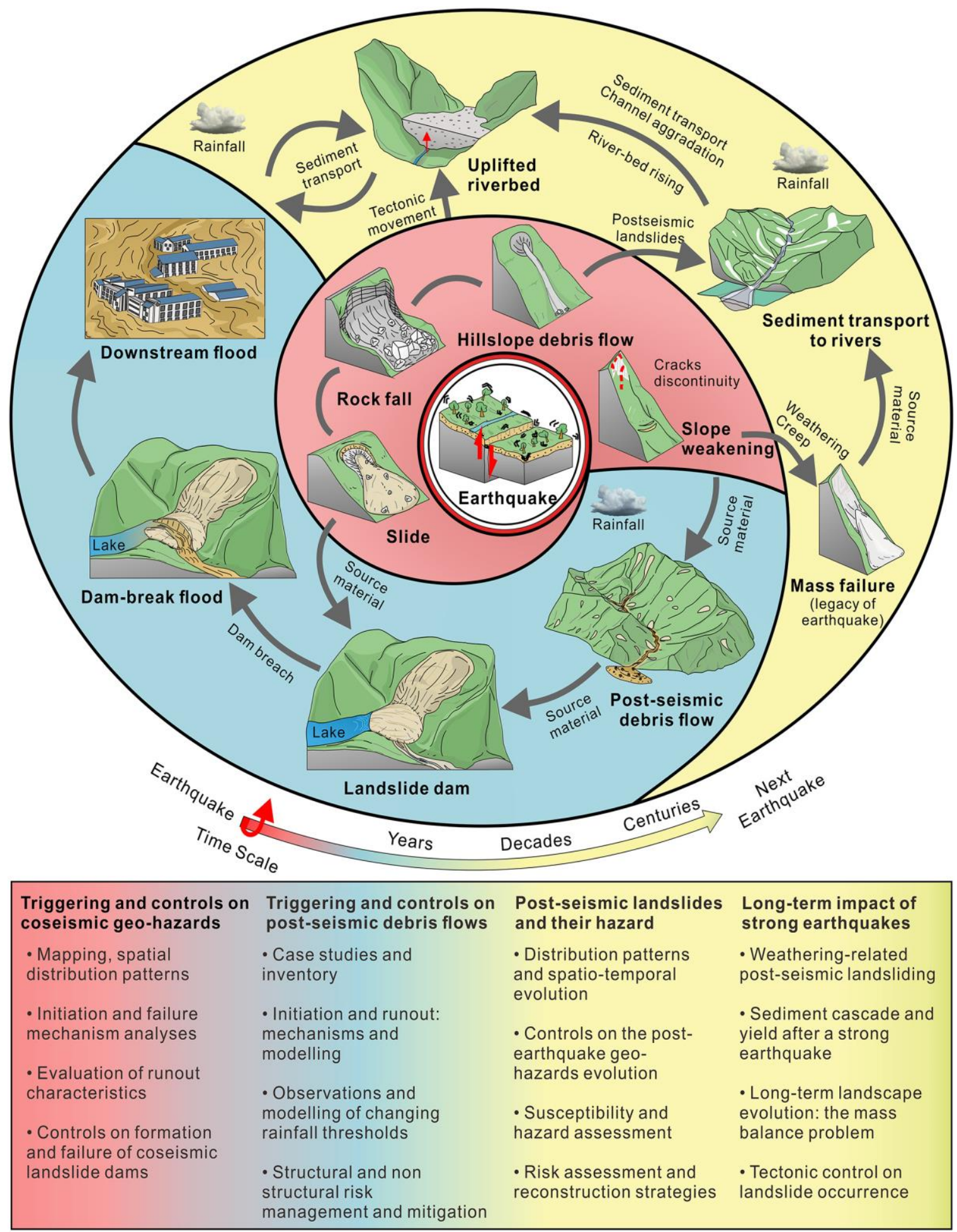

Figure 4: Chains of geologic hazards triggered by a strong continental earthquake - causal relations between hazards are indicated. The red background shows different types of coseismic landslides; blue indicates the post-seismic cascade of hazards in days to years later; and yellow represents the long-term impact of an earthquake, years to decades later, and perhaps longer (from Fan et al., 2019).

Slika 4: Zaporedja geoloških nevarnosti, sproženih z močnim kontinentalnim potresom - prikazane so vzročne povezave med nevarnostmi. Rdeče ozadje prikazuje različne vrste koseizmičnih zemeljskih plazov; modro ozadje označuje popotresno zaporedje nevarnosti $v$ dnevih in letih po potresu; in rumeno ozadje predstavlja dolgoročni vpliv potresa, v letih in desetletjih po potresu, morda tudi dlje (po Fan et al., 2019). 


\section{Field and laboratory investigations of the 2000 Stože Landslide and beyond}

\subsection{Hydrological investigations}

The hydrological investigations in the field were oriented towards the possible triggering factors for the debris slide on the Stože slope and the dry debris flow (first phase) and the consecutive wet debris flow (second phase). All available precipitation data were collected, discharge in the Mangart Creek was measured using the salt dilution method, water samples from the area were subjected to chemical analysis, along with an analysis of tritium $\left(\delta^{18} \mathrm{O}\right)$; infiltration into soils was also measured in the landslide area (Mikoš et al., 2002d). As a result of field investigations and based on available data, a hydrological model of the Koritnica River basin was constructed using Watershed Modelling System (WMS) and HEC-1 model - the digital terrain model was $20 \times 20 \mathrm{~m}$ (Brilly et al., 2001). The hydrologic conditions responsible for triggering the 2000 Stože Landslide were summarised as follows: the landslide on the Stože slope was triggered by high artesian pressures built in the slope due to slow exfiltration of relatively high permeable $\left(10^{-5} \mathrm{~m} / \mathrm{s}\right)$ massive dolomite covered by morainic material of relatively low permeability $\left(10^{-7} \mathrm{~m} / \mathrm{s}\right)$ after a longduration rainfall (Mikoš et al., 2004b). The recorded rainfall in the area in the 48 days before the event has a recurrence interval of more than 100 years (1.42 mm/h in 1152 hours or $1638.4 \mathrm{~mm}$ in 48 days).

Furthermore, a sediment budget study of the Koritnica River basin was conducted (Mikoš et al., $2002 \mathrm{a} ; 2002 \mathrm{c}$ ) in order to estimate the impact of such a large debris flow on the sediment processes of the Koritnica River and its morphological changes (Mikoš et al., 2002b). These investigations helped to propose a nature-based remediation of the devastated channels of the Predelica Torrent and the Koritnica River by stimulating natural incision processes into the debris-flow deposits (Mikoš et al., 2003; 2004c; Mikoš and Fazarinc, 2005). Later on, this optimisation for river engineering plans in the devastated area around Log pod Mangartom was supported by the results of mathematical modelling of debris flow (Fazarinc et al., 2006).
The impact of large mass movements on sediment budget of large river basins was studied in the Upper Soča River, where sediment production and delivery from recent large landslides, including the 2000 Stože Landslide, and earthquake-induced rock falls was estimated (Mikoš et al., 2006b). Field experience that was gained when analysing the rock falls triggered by 1998 Soča Earthquake on the Tolminka River were employed (Mikoš and Fazarinc, 2000).

Furthermore, the impact of the 2000 Stože Landslides and increased sediment supply from the Koritnica River on the changes of the braided pattern of the Soča River at Čezsoča was studied (Ranfl, 2010).

As numerous small and large landslides in Slovenia are triggered during heavy short-term rainfall events (Mikoš et al., 2004a; Mikoš and Majes, 2008), the focus in Slovenia is on rainfall-induced landslides more than on quake-induced ones that though exist (Mikoš et al., 2013). For prevention against shallow landslides (slides, slips, slumps) statistical analysis of so-called intensity-duration frequency (IDF) curves using rainfall data are in use. The first such relationship (threshold curve) was introduced by Caine (1980) by combining rainfall intensity $I$ $(\mathrm{mm} / \mathrm{h})$ with its duration $D(\mathrm{~h})$ data. After that, numerous local and global thresholds were defined, but not for Slovenia.

The first definition of rainfall thresholds for rainfallinduced landslides in Slovenia was presented by Rosi et al. (2016). The thresholds were calculated by collecting 892 landslide data from the Slovenian National landslide database, and the relative rainfall amounts, which have been collected from 41 rain gauges. The country was divided into 4 regions (NW Slovenia, Drava, Mura, and Sava) and empirical threshold curves defined. The curve for the whole of Slovenia:

$I\left(\frac{m m}{h}\right)=37.7 D^{-0.68}(h)$

is for the rainfall duration $D$ less than 24 hours above the threshold curve proposed by Caine (1980):

$I\left(\frac{m m}{h}\right)=14.82 D^{-0.39}(h)$ 
A more sophisticated approach was taken by Bezak et al. $(2016$; 2017) by applying the Frank copula function for the determination of intensity-durationfrequency (IDF) relationships for selected 16 rainfall stations in Slovenia. Post-event analyses of seven extreme hydrological events in Slovenia in the past 25 years showed that rainfall characteristics triggering flash floods and landslides are different. Deep-seated landslides were induced by longer duration rainfall events (up to one or few weeks); however shallow landslides were triggered by rainfall events with durations from a few hours to one or two days. A combination of several proposed empirical rainfall thresholds with an appropriate high-density rainfall measurement network can be used as part of the early warning system of the initiation of landslides and debris flows in Slovenia (Bezak et al., 2018). However, different rainfall threshold curves should be used for lowland and mountainous areas in Slovenia for this purpose. Furthermore, the results indicate that inter-event time selection can have significant influence on the location of a rainfall event in the intensity-duration space. Consequently, the selected inter-event time value also influences the location of a rainfall event regarding the ID thresholds (above or under the threshold) (Bezak et al., 2016).

Since in some rainfall-triggered landslides, intensity-duration thresholds can have limited prediction ability, Bezak et al. (2019a) developed a methodology for predicting rainfall-induced shallow landslides based on a lumped conceptual hydrological model. The model was better predictor for shallow landslides than local, regional, and global Intensity-Duration thresholds for the Selška Sora River catchment. Only daily rainfall, evapotranspiration, and discharge data are needed to calibrate the selected hydrological model, and only daily rainfall and evapotranspiration to run the model. So, the presented approach could be useful for data-scarce areas where detailed physically based landslide prediction models that require many data cannot be constructed.

\subsection{Geological-geotechnical investigations}

The geological-geotechnical investigations started immediately after the catastrophic event in
November 2000. On one hand, they were needed to understand the event (process), especially the landslide triggering factors, and on the other hand to plan remediation measures in the source area to lower potential risk in future. Special focus was put on rheological properties of local geological materials on the Stože slope and its potential to liquefy. A series or reports and publications witnesses about these efforts. Rheological properties of materials on the Stože slope and of the debris deposits were studied in geotechnical laboratory with a focus on their rheological properties such as liquefaction potential, thixotropic clays behaviour when in suspension, and structural collapse of material (Petkovšek, 2001a; 2002). These important soil properties were put into a spatial framework by extensive field mapping, producing detailed engineering geological map of the source area (Petrica and Špacapan, 2001; Petkovšek, 2001b).

Lenart studied deformation characteristics of the landslide materials from the Stože landslide in a series of papers (Lenart 2004; 2006; 2008; Žlender and Lenart, 2005). He applied a large-scale shear cell (box), using grains up to $45 \mathrm{~mm}$, and a resonant column for fines below $4 \mathrm{~mm}$ (Lenart, 2004). The extent to which characteristics of Lacustrine carbonate silt change due to increasing shear strain depend on a number of factors, such as the degree of saturation, the initial void ratio, overconsolidation, and the effective stresses (Lenart, 2006). The focus was on the dynamic response of saturated soils during cyclic loading (e.g. earthquake) in a cylindrical triaxial apparatus with a cell leading to increased water pore pressures under undrained soil conditions (Žlender and Lenart, 2005; Lenart 2006; 2008). The saturated soils may be susceptible to cyclic mobility or flow liquefaction. They found that Lacustrine carbonate silt is a highly sensitive material that have somewhat higher resistance to liquefaction that that of a typical clean sand (Žlender and Lenart, 2005). On the basis of experimental results using the Lacustrine carbonate silt, Lenart (2011) further theoretically studied the relations between dissipated energy and pore pressure changes in saturated cyclic loaded soils. 
Soon after the 2000 Stože Landslide occurred, a comparison between landslide materials from several deep-seated landslides in Slovenia triggered around 2000 came into focus of laboratory investigations. They were based on geological and geomechanical data gathered during intense field investigations. For the Slano Blato landslide, Kočevar and Ribičič (2002) reported on the geological, hydrogeological and geomechanical investigations. A comparison of rheological properties of materials from several large landslides in Slovenia was reported using a laboratory rheometer and fraction $<63 \mu \mathrm{m}$ that supported field observations of their behaviour (Majes et al., 2002a). Lenart and Fifer Bizjak (2010) studied material properties from the Stože and Slano Blato landslides in the large-scale shear box. They can confirm different properties leading to a debris flow at the Stože landslide and to an earth flow at the Slano Blato landslide.

In 2004, the Faculty of Civil and Geodetic Engineering, University of Ljubljana, started laboratory measurements in soil suction for geotechnical purposes (Maček, 2006a; 2006b; Maček and Petkovšek, 2008; Petkovšek, 2006). The main field expertise for these mechanisms was the Slano Blato landslide and not the Stože landslide anymore (Maček, 2012). In order to better understand the suction variation inside the earthflow body and the drying-wetting processes, three representative locations on the Slano Blato landslide were instrumented with suction probes in 2007. The results of the 6-year monitoring program on the Slano Blato landslide showed that only prolonged wet periods change the suction in the earthflow body. A sudden decrease in suction was observed in the case of depths of up to $1.0 \mathrm{~m}$ during rainfall events in high suction periods, indicating the propagation of desiccation cracks to the depth of the suction probes. Suction variation were not the result of de-saturation, but rather of volume deformation (i.e. shrinkage) (Maček et al., 2016).

Soil suction was applied in geotechnical engineering in Slovenia (Petkovšek, 2008; Petkovšek, 2009a), as well as using soil matric suction as an indicator for mudflow occurrence on the Slano Blato landslide (Petkovšek et al., 2009b).
The landslide research focus moved to mechanisms of landslides in over-consolidated clays and flysch (Mikoš et al., 2009). The Slano Blato landslide was the main field polygon (Maček et al., 2012a; 2012b), and the Slano Blato landslide was a case study for studying landslide dynamics in overconsolidated clays and flysch (Mikoš et al., 2014). Landslides in flysch-like rocks were compared between Slovenia and Croatia (Maček et al., 2017a). Laboratory investigation on intact specimens of residual soils (type CL) from weathered flysch rock masses was conducted to establish soil-water characteristic curves (Peranić et al., 2018). The results can be applied to assess the influence of desaturation of the residual soil covering flysch slopes during dry summer periods by providing keyin material properties required to analyse the transient rainfall infiltration process.

Due to the activation of several landslides in the torrential catchment of the Koroška Bela in NW Slovenia, since 2017, again debris flows are in the focus of landslide research in Slovenian laboratories. Maček et al. (2017b) studied the influences of the rheometer size and the grain size on rheological parameters of debris flows by applying larger ConTec Viscometer 5 for grains up to $22.4 \mathrm{~mm}$ and the smaller Brookfield DV3T HB rheometer for suspensions. The targeted material for rheological properties was from the Stože Landslide.

Recently, the same two rheometers were used to assess the rheological parameters of selected debris materials in the Bingham rheological model (yields stress, plastic viscosity). The obtained results were compared to those obtained using standardised laboratory equipment (different cones and funnels) to determine the flowability and consistency of construction materials such as concrete or grouts (Jurček, 2020). Such applications need further refinement to be used to assess the rheological properties of natural debris.

\subsection{Remote sensing studies}

The first international response to the 2000 Stože Landslide was in the field of remote sensing. The International Charter on Space and Major Disasters 
(www.disasterscharter.org) is a worldwide collaboration, through which satellite data are made available for the benefit of disaster management. The Charter has nowadays 17 members, among others the European Space Agency (ESA), and the Charter offers data 61 satellites. Until the end of 2020, altogether nearly 700 activations in over 120 countries were initiated. The Charter was first activated precisely for the 2000 Stože Landslide on 27 November 2000 (ESA, 2000). This event in Slovenia is therefore an important milestone for using remote sensing in natural disaster monitoring. The next time the Charter was activated was after the 2007 Železniki Flood.

For the purpose of the terrain analysis before and after the 2000 Stože Landslide, all available satellite images (multi-spectral optical and radar) have been integrated within a geographical database, together with DEM (digital elevation model) and land use map (Oštir et al., 2003). For landslide volume estimation and for estimation of debris-flow deposit height in the Koritnica River valley bottom, a $25 \mathrm{x}$ $25 \mathrm{~m}$ DEM was put in place, made from ERS (European Remote Sensing) images with radar interferometry and advanced modelling. Spaceborn data were also combined with airborne data (photogrammetric) gathered from a helicopter. The DEM was used for immediate assessment of risk in the event of further debris flows from the Stože slope, as well as for debris-flow modelling in the area.

Baron et al. (2013) performed an airborne multisensory geophysical survey using airborne frequency domain electromagnetics (AEM), a magnetic survey, and a gamma ray survey, of the 2000 Stože Landslide devastation area, in the landslide triggering area, and along the pathway of the debris flow. They found that:

i) the AEM survey confirmed the lithological pattern and water saturation within the test area;

ii) the airborne magnetic survey provided for such a small area with such a high relative relief that it is unfortunately inapplicable;

iii) the gamma ray survey shows very promising results for landslide studies; the method identified regions relatively rich in clay, weathered zones along some tectonic faults, i.e. zones with a lithology prone to mass wasting.

All in all, airborne geophysical surveys, especially due to their relatively low resolution in contrast to ground-based geophysical methods, provide information on the bedrock properties of more extensive areas rather than on the landslides' internal structure. They also concluded that the applied methods were promising, but several hours of training flights are needed, as well as waiting for suitable weather conditions to improve the quality of results.

Jemec and Mikoš (2008) analysed satellite images (2.5 and $5 \mathrm{~m}$ resolution SPOT-5 images; www.satimagingcorp.com) to determine landslide occurrences from them, and to compare obtained results from supervised and unsupervised classification of satellite images to detect activated landslides during this extreme event with the classes of landslide susceptibility map of the area (Jemec Auflič and Mikoš, 2009).

After 2007, one remote sensing, space-born radar technique proved its usefulness for landslide monitoring in Slovenia, namely the PSInSAR (Permanent Scatterer Interferometric Synthetic Aperture Radar) (Komac et al., 2012; Jemec Auflič, 2012). One of the first studies was performed by Komac and Bavec (2007), observing subtle surface displacements in the NW part of Slovenia between April 1992 and December 2000. They concluded that the method proved to be useful for relative tectonic displacement velocity and as a tool to detect co-seismic surface displacements, such as during and after the 12 April 1998 Earthquake in the Soča River valley. From the same set of $>4300$ permanent scatters recognised in Slovenia, Žibert et al. (2012) related PSInSAR displacement with soil creep and rainfall intensities in two study areas in $\mathrm{W}$ Slovenia.

The remote sensing data gathered by the radar interferometry method were soon combined with insitu data by GPS/GNSS (Global Positioning System / Global navigation Satellite System) for the Potoška Planina landslide study area above the Koroška Bela (Komac et al., 2015). The Koroška Bela alluvial fan was recognised as a product of 
recent catastrophic events, including debris flows (Jež et al., 2008), and got attention due to several active landslides in the hinterland.

Further survey techniques were applied for the Potoška Planina landslide periodically over 22.5 months for landslide surface movement detection: tachymetric measurements and UAV-based photogrammetry (UAV stand for Unmanned Aerial Vehicle) (Peternel et al., 2017). Furthermore, a lowcost GNSS system (Global Navigation Satellite System) was successfully tested over the period of nine months and correlated with precipitation measurements at site for further development of an early warning system (Šegina et al., 2020). A simple terrestrial hand-held laser measurement system had already been applied to monitor surface morphological changes on the Strug landslide (Mikoš et al., 2005).

Recognition and monitoring of landslides is gathering a real impetus using advanced terrestrial and remote sensing techniques. This is especially important for planning early warning systems and drawing up hazard and risk maps in landslide prone areas. This is discussed in the companion paper (Mikoš, submitted).

\section{Numerical modelling of debris flows}

One- and two-dimensional numerical modelling of debris floods, debris flows, mudflows, earth flows, and other flow-like mass movements started to become a necessity, as these types of landslides became more and more frequent, inter alia due to climate change. As all these flows are typically nonNewtonian fluids resp. multi-phase flows, their numerical modelling is far from being a trivial task. In Slovenia, before the Stože 2000 Landslide, numerical modelling of non-Newtonian fluids was developing at the Faculty of Architecture, Civil and Geodetic Engineering of the University of Ljubljana (UL FAGG) and applied for snow avalanches and dam-break flows (Rajar, 1978; 1980; 1982).

To model debris flow, one needs to know the release area (source area), have an estimate of the event magnitude (hydrograph volume, block release in the event of an instantaneous dam break or landslide collapse), precise geometry data (cross sections, digital elevation model, digital terrain model), roughness data for the pathway, data on debris flow (water-sediment mixture) properties, and especially rheological properties to estimate energy losses within the debris flow during transport. The results of a numerical debris-flow model can be: flow depth, flow velocity, impact loads, runout zone, etc. In the event of post-event debris-flow analysis, a numerical model can be calibrated and used for future events. If no local data on past events are available, potential scenarios for possible debris flows should be estimated in order to prepare hazard and risk maps, or to design structural countermeasures.

A short review of the development in the field of debris-flow numerical modelling in Slovenia since 2000 is given.

\subsection{Debris-flow magnitudes}

The first estimation of the magnitudes of debris flows in 24 torrential watersheds in Slovenia of the size from $1 \mathrm{~km}^{2}$ to several $10 \mathrm{~km}^{2}$ was made by Sodnik and Mikoš (2006a; 2006b). Firstly, they developed empirical equations for 100-year design floods. Secondly, they used seven empirical methods and compared them to get debris-flow magnitudes in these watersheds between $6,500 \mathrm{~m}^{3}$ and $340,000 \mathrm{~m}^{3}$. Finally, the investigated fans were classified into 3 groups with regard to the debrisflow hazard: debris-flow fans (hazard exists), torrential fans (no hazard), and transitional fans (debris flows are possible, but with low possibility).

Dendrogeomorphology has proven to be a highly useful method in studies of past slope mass movements. Oven et al. (2019) reconstructed landslide activity over the past 138 years using dendrogeomorphological analysis in the form of tree ring eccentricity in the Karavanke Mountains in NW Slovenia - on the Urbas Landslide at Potoška Planina above the settlement of Koroška Bela. Novak et al. (2020) developed a method that directly estimates the magnitudes of past debrisflood events on an alluvial fan using dendrogeomorphological and meteorological data sets. As the study area the Planica valley in NW Slovenia was selected, especially the complex 
Ciprnik landslide (Šmuc et al., 2015). This approach seems promising to estimate of magnitudes of historical events for the case of debris floods that can be used as the estimated values for design floods when planning structural measures or producing debris-flood hazard maps. Novak et al. (2018) produced a geomorphological map on a scale $1: 15,000$, with detailed sedimentological descriptions, and a general relative spatio-temporal depositional reconstruction of Quaternary sediments in the Planica valley. These results stress the need to produce more such geomorphological maps in small scales in order to draw up hazard maps for torrential events such as debris flows and debris floods on the basis of past events.

The integrated LS-Rapid model (https://soft.godai.co.jp/En/Soft/Product/Products/ LS-RAPID/) is a 3D landslide simulation model, and was developed to assess the initiation and motion of landslides triggered by earthquakes, rainfalls, or their combined effect (Sassa et al., 2010). Such a modelling approach replaces a twostep procedure: i) a separate assessment of a debrisflow magnitude to be used in a block release or as a hydrograph, and ii) debris-flow motion, by incorporating them in a single coupled model.

The LS-Rapid model was tested in the hinterland of the Koroška Bela torrential watershed in NW Slovenia (Sodnik et al., 2017), and a good agreement of the LS-Rapid model results (identified landslide sources as a sediment source for potential debris flows) with the GIS-based landslide susceptibility model of the area was achieved. Furthermore, the LS-Rapid model was applied in the source area of the 2000 Stože Landslide by Sodnik et al. (2018a; 2018b). The model was recognised as a useful tool for landslide triggering simulations with strong dependence of the simulated landslide volumes on soil properties and on soil depth. Such data are not readily available, and using this model is advised for post-event studies much more than for estimating volumes of potentially triggered landslides. There is urgent need in Slovenia for engineering geology maps at scales 1:10,000 with more detailed data on the depth of soils to be used in studies on slope stability and triggering of large deep-seated) landslides.
The use of LS-Rapid is nevertheless proposed as a constituent part of a novel procedure for debris-flow hazard assessment on torrential fans (Sodnik, 2017).

\subsection{One- and two-dimensional numerical modelling of debris flows}

As a part of planning remediation measures in the devastated area of the 2000 Stože Landslide and to plan and design countermeasures in the event of potential new debris flows, numerical modelling of debris flows from the Stože slope was performed.

The one-dimensional model, DEBRIF1D, was first used for simulations along the upper part of the affected region, where the debris flow was mainly in a narrow canyon - distance between cross sections was $20 \mathrm{~m}$ (Rajar et al., 2001). Hydrographs of the debris-flow discharge at the upstream end of the affected village of Log pod Mangartom were thus determined for possible future landslides. Twodimensional simulations of the debris flow in the village were carried out using two models: PCFLOW2D, developed at the University of Ljubljana (numeric grid $2 \times 2 \mathrm{~m}$ ); and a commercial model, FLO-2D (numeric grid 4 x $4 \mathrm{~m}$ ) (Hojnik et al., 2001; Četina et al., 2002). The three models were successfully calibrated using field measurements of the debris-flow maximum levels in the Predelica gorge and the inundation limits in the Koritnica River valley, and considering the results of geomechanical laboratory experiments for assessment of rheological properties of the debris material (described in Section 4.2). A sensitivity analysis of the two-dimensional model PCFLOW2D with different grid sizes $(2 \times 2 \mathrm{~m}$ and $4 \times 4 \mathrm{~m}$ - Fazarinc, 2002) and two different outflow boundary conditions was also made (Četina and Krzyk, 2003). The review paper on modelling 2000 Stože Landslide and its dry and wet debris flow with a magnitude of $1.2 \mathrm{mil} . \mathrm{m}^{3}$ was published as a case study in Journal of Hydraulic Engineering of the American Society of Civil Engineers (ASCE) (Četina et al., 2006).

The calibrated two-dimensional numerical debrisflow model was also used to optimise the Koritnica River channel form to convey debris flows and floods (Fazarinc et al., 2006) by stimulating natural 
processes of erosion of debris-flows deposits (Mikoš et al., 2004c; Mikoš and Fazarinc, 2005). Furthermore, the calibrated two-dimensional numerical model for debris flows was applied to produce risk map of the Log pod Mangartom area after implementing proposed structural measures in the event of future debris flows triggered on the Stože slope - the first risk map produced of its kind in Slovenia (Mikoš et al., 2007). The main counter measure was a massive 11-m high RC (reinforced concrete) debris-flow breaker in the Predelica Torrent just upstream of its confluence with the Koritnica River and above the village of Log pod Mangartom, first of this kind in Slovenia (Mikoš and Kryžanowski, 2011).

The experiences gathered by modelling debris flows in Log pod Mangartom were transferred to other such cases in Slovenia. An overview of debris-flow characteristics was made by Fazarinc et al. (2002), including a comparison of the Log pod Mangartom case study with a set of debris flows triggered in the 2001 Strug Landslide area. This was a case of a complex multi-process phenomenon (Mikoš et al., 2006a). In 2002, more than 20 debris flow events of clayey gravels with a volume up to $1000 \mathrm{~m}^{3}$ triggered from rockfall deposits in the source area were registered. Two mathematical models were used, a one-dimensional model DEBRIF-1D, and a two-dimensional commercially available model FLO-2D (Hojnik, 2004; Mikoš et al., 2006c). The results of the numerical modelling of potential debris flows with a magnitude up to $25,000 \mathrm{~m}^{3}$ as the extreme case scenario were used to draw up a hazard map for the area around the Koseč village below the Strug landslide source area. The calibration was made using video footage of one dry and one wet debris flow event.

A 2D model Flo-2D was also applied for potential debris flows - where no post-event analysis is possible. The influence of the selection of the model rheological properties (critical shear strength $\tau_{c}$, viscosity $v$ ) on the runout on the Koroška Bela fan was estimated (Sodnik et al., 2009a). The numerical grid was $15 \times 15 \mathrm{~m}$ and no big influence on the runout distance was detected using the constant volumetric concentration of a debris flow ( $C_{v}$ values $0.4,0.45$, and 0.5 were tested).
The Flo-2D model was also applied for potential debris flows from the active landslides in the Hrenovec torrential watershed above the village of Kropa in NW Slovenia (Sodnik and Mikoš, 2010). The rheological properties of the debris material were assessed from literature, mostly based on the experiences from the Stože Landslide case. The scenario with a debris flow of a magnitude 50,000 $\mathrm{m}^{3}$ shows potential catastrophic consequences in the village of Kropa, much worse than caused by a torrential flood during a storm on 18 September 2007. During this extreme event, only a small debris flow was initiated from a small landslide that luckily stopped upstream of the village. The problem of how to assess model parameters for any debris-flow numerical model to be used for potential debris-flow cases remained unsolved.

Another empirical debris-flow model, the TopRunDF model was applied on a $12.5 \mathrm{~m}$ digital elevation model to assess the protective function of forests against debris flows in the Soteska gorge of the Sava Bohinjka River in W Slovenia (Fidej et al., 2015). The model sensitivity analysis showed that the mobility coefficient (MC) is its most significant factor. It has proved to be applicable only if the field conditions are comparable to those for which it has been developed.

In 2018, the RAMMS model with its debris-flow module (Rapid Mass Movement Simulations; https://ramms.slf.ch/ramms/) was tested for modelling debris flows modelling and simulations of torrential fan forming (Kaltak, 2018). He performed sensitivity analysis using the model and he used it for building up an artificial fan; furthermore, he made a simulation of the debris flow in Log pod Mangartom 2000 by using grid $4 \mathrm{x}$ $4 \mathrm{~m}$ and values for the model rheological parameters: $\mu=0,075$ and $\xi=200 \mathrm{~m} / \mathrm{s}^{2}$ to get comparable results with the previous studies using PCFLOW2D and Flo-2D (Hojnik et al., 2001). He concluded that RAMMS is potentially applicable for the both aforementioned tasks.

Mikoš and Bezak (2021) reviewed the applications of the RAMMS model (Rapid Mass Movement Simulations RAMMS; https://ramms.slf.ch/ramms/) with its debris flow 
module. A comprehensive review of past debris flow modelling studies in the alpine environment includes their main characteristics including study location, debris-flow magnitude, simulation resolution (i.e. numerical grid resp. digital elevation model), and Voellmy-fluid friction model parameters ranges (i.e. $\mu$ and $\xi$ ). Additionally, a short overview of each study is provided. Based on the conducted review, it is clear that RAMMS parameter ranges were relatively broad and that model calibration using debris-flow post-event survey field data is the essential step that should be taken before application of the model. However, an overview of the parameters can help limit the parameter ranges if someone were to take into consideration the similarity of relevant case studies that were conducted in similar environments, provided the model should be applied for estimation of debris-flow hazard for potential future events.

The RAMMS model and its debris flow module was also used to form a torrential fan from hypothetical debris flows. As a case study the Suhelj fan in NW Slovenia was chosen (Bezak et al., 2019b) since it has been classified as a debris-flow fan (Sodnik and Mikoš, 2006a). A significantly different new topography was built upon the original Suhelj fan topography by random sequences of 62 debris flows of a magnitude between $100 \mathrm{~m}^{3}$ and $20,000 \mathrm{~m}^{3}$ and in total volume of $225,000 \mathrm{~m}^{3}$.

The RAMMS model was calibrated using the extreme May 2018 debris flood in Brezovški and Lukenjski graben torrents below the Krvavec ski area close to the City of Ljubljana (Bezak et al., 2020). The estimated magnitude of the May 2018 flood was $4,000 \mathrm{~m}^{3}$. For future debris floods and debris flows, a 5-m high slit check dam with 14,000 $\mathrm{m}^{3}$ retention volume and a slit width of $0.8 \mathrm{~m}$ was planned just downstream of the confluence of the both torrents. The results from debris flood numerical modelling (maximum flow pressures) were used for the check dam structural design.

\subsection{Digital terrain models (DTMs) and Digital elevation models (DEMs)}

Debris flow hazard and risk assessment is not only based on assumptions about source areas and magnitudes of possible debris flows and their rheological characteristics, but also on their runout predictions (Sodnik et al., 2009b). Which digital terrain models (DTMs) or digital elevation models (DEMs) should be used in debris-flow numerical models to get reliable runout predictions? On one hand, computational times increase along with the refinement of the numerical grid, which must be in accordance with the underlying digital elevation or digital terrain models. On the other, calibration of the numerical is possible with observed field data only and if the geometrical description of the terrain is to some extent fine enough.

Sensitivity analyses of the Flo-2D model for the Trebiža torrential fan using numerical grid $5 \times 5$ and $15 \times 15$ m generated from DEM5 and numerical grid $12.5 \times 12.5 \mathrm{~m}$ from DEM12.5 showed that DEM 12.5 can be more geomorphologically representative (Sodnik et al., 2009b; 2010). Furthermore, they showed that regarding debrisflow numerical modelling buildings that are not shown on DEMs should be modelled, because they have large influence on the flow field close to them.

Because of the questionable morphological accuracy of DEM12.5 and DEM5, LiDAR-derived terrain data (LiDAR DTM0.5, LiDAR DTM5) with higher resolution were applied for debris-flow modelling of the Koroška Bela torrential fan using the Flo-2D model (Sodnik et al., 2012a; 2012b). The results showed that the LiDAR DEM data are more accurate than the public DEM5 or DEM12.5, especially when representing torrential channels into much more detail, and hence better follow field conditions, including flow around buildings on the fan. Hence, better debris-flow hazard maps can be produced (Sodnik et al., 2013). The experiences in Slovenia regarding topographic data and twodimensional debris-flow modelling were collected into a teaching tool published by Springer Verlag (Sodnik and Mikoš, 2018).

An overview of landslide research papers published with papers from Slovenian authors on various topical content sets described in this paper is given in Table 1. 
Mikoš M.: After 2000 Stože Landslide: Part I - Development in landslide research in Slovenia - Po zemeljskem plazu Stože leta 2000: Del I - Razvoj raziskovanja zemeljskih plazov v Sloveniji

Acta hydrotechnica 33/59 (2021), 129-153, Ljubljana

Table 1: Overview of landslide research papers classified by topical sets of research content.

Preglednica 1: Pregled raziskovalnih člankov o zemeljskih plazovih, vsebinsko razdeljenih v tematske sklope.

\begin{tabular}{|c|c|}
\hline Thematic set of content & Research papers in the chronological order of their publication \\
\hline $\begin{array}{l}\text { The } 2000 \text { Stože Landslide } \\
\text { event, its consequences and } \\
\text { remediation }\end{array}$ & $\begin{array}{l}\text { Brilly et al. (2001), Gostinčar (2001), Hojnik et al. (2001), Horvat (2001), Komac } \\
\text { (2001), Majes (2001a; 2001b), Majes and Petkovšek (2001), Majes et al. (2001), } \\
\text { Mikoš (2001), Ribičič (2001), Ribičič and Vidrih (2001), Zlodej (2001), Brilly et al. } \\
\text { (2002), Fazarinc et al. (2002), Majes and Beseničar (2002), Majes et al. (2002b; 2002c; } \\
\text { 2002d), Zorn and Komac (2002), Mikoš et al. (2004c), Mikoš and Fazarinc (2005), } \\
\text { Fazarinc et al. (2006), Mikoš et al. (2007), Komac and Zorn (2008), Mikoš and } \\
\text { Fazarinc (2011), Lenart (2016) }\end{array}$ \\
\hline $\begin{array}{l}\text { Mitigation of large landslides } \\
\text { in Slovenia }\end{array}$ & $\begin{array}{l}\text { Zorn and Komac (2004), Majes (2005), Mikoš et al. (2006a), Zorn et al. (2006), Mikoš } \\
\text { and Majes (2008, 2010), Petkovšek et al. (2011), Jemec Auflič et al. (2017) }\end{array}$ \\
\hline $\begin{array}{l}\text { e-related } \\
\text { ogy }\end{array}$ & $\begin{array}{l}\text { Mikoš (1995, 2000), Gams (2001), Mikoš (2001), Ribičič (2001), Skaberne (2001), } \\
\text { Ribičič (2002), Skaberne (2002), Geološki terminološki slovar (2006), Geografski } \\
\text { terminološki slovar (2013) }\end{array}$ \\
\hline $\begin{array}{l}\text { Hydrological investigations } \\
\text { related to } 2000 \text { Stože } \\
\text { Landslide }\end{array}$ & $\begin{array}{l}\text { Brilly et al. (2001), Mikoš et al. (2002a; 2002b; 2002c; 2002d), Mikoš et al. (2003), } \\
\text { Mikoš et al. (2004b; 2004c), Mikoš and Fazarinc (2005), Fazarinc et al. (2006), Mikoš } \\
\text { et al. (2006b), Ranfl (2010) }\end{array}$ \\
\hline $\begin{array}{l}\text { Investigations on rainfall- } \\
\text { induced landslides }\end{array}$ & $\begin{array}{l}\text { Mikoš et al. (2004a), Komac and Zorn (2007), Mikoš and Majes (2008), Zorn and } \\
\text { Komac (2008), Bezak et al. (2016), Rosi et al. (2016), Bezak et al. (2017; 2018; } \\
\text { 2019a), }\end{array}$ \\
\hline $\begin{array}{l}\text { Geological-geotechnical } \\
\text { investigations related to } 2000 \\
\text { Stože Landslide }\end{array}$ & $\begin{array}{l}\text { Petkovšek (2001a; 2001b), Petrica and Špacapan (2001), Kočevar and Ribičič (2002), } \\
\text { Majes et al., (2002a), Lenart (2004), Žlender and Lenart (2005), Lenart (2006; 2008; } \\
\text { 2011) }\end{array}$ \\
\hline $\begin{array}{l}\text { Investigations on suction and } \\
\text { rheological properties of } \\
\text { landslides in flysch-like rocks }\end{array}$ & $\begin{array}{l}\text { Maček (2006a; 2006b), Petkovšek (2006), Maček and Petkovšek (2008), Petkovšek } \\
\text { (2008), Mikoš et al. (2009), Petkovšek (2009a; 2009b), Lenart and Fifer Bizjak (2010), } \\
\text { Maček (2012), Maček et al. (2012a; 2012b), Mikoš et al. (2014), Maček et al. (2016; } \\
\text { 2017a; 2017b), Peranić et al. (2018), Jurček (2020) }\end{array}$ \\
\hline Remote sensing studies & $\begin{array}{l}\text { Oštir et al. (2003), Mikoš et al. (2005), Komac and Bavec (2007), Jemec and Mikoš } \\
\text { (2008), Jemec Auflič and Mikoš (2009), Jemec Auflič (2012), Komac et al. (2012), } \\
\text { Žibert et al. (2012), Baron et al. (2013), Komac et al. (2015), Peternel et al. (2017), } \\
\text { Šegina et al. (2020) }\end{array}$ \\
\hline $\begin{array}{l}\text { Estimation of debris-flow } \\
\text { magnitudes }\end{array}$ & $\begin{array}{l}\text { Sodnik and Mikoš (2006a; 2006b), Šmuc et al. (2015), Sodnik et al. (2017), Novak et } \\
\text { al. (2018), Sodnik et al. (2018a; 2018b), Oven et al. (2019), Novak et al. (2020) }\end{array}$ \\
\hline $\begin{array}{l}\text { Mathematical modelling of } \\
\text { debris flows }\end{array}$ & $\begin{array}{l}\text { Hojnik et al. (2001), Rajar et al. (2001), Četina et al. (2002), Fazarinc (2002), Četina } \\
\text { and Krzyk (2003), Hojnik (2004), Četina et al. (2006), Mikoš et al. (2006c), Sodnik et } \\
\text { al. (2009a), Sodnik and Mikoš (2010), Fidej (2015), Kaltak (2018), Bezak et al. } \\
\text { (2019b; 2020), Mikoš and Bezak (2020) }\end{array}$ \\
\hline $\begin{array}{l}\text { Terrain representation for } \\
\text { mathematical modelling } \\
\text { (DTMs and DEMs) }\end{array}$ & Sodnik et al. (2009b; 2010; 2012a; 2012b, 2013), Sodnik and Mikoš (2018) \\
\hline
\end{tabular}




\section{Conclusions}

The 2000 Stože Landslide sparked more interdisciplinary landslide research in Slovenia on one hand, and a more technologically supported field and laboratory investigation of landslide dynamics on the other hand. This cooperation also led to a membership of several academic institutions in Slovenia (University of Ljubljana, Faculty of Civil and Geodetic Engineering \& Faculty of Natural Sciences and Engineering, Geological Survey of Slovenia) in the International Consortium on Landslides, Kyoto, Japan (https://icl.iplhq.org/). This development supports knowledge transfer in landslide disaster risk reduction and landslide research to Slovenia and about our experiences to the world community.

Risk dialogue in landslide disaster risk reduction in Slovenia found a way to increase media exposure, culminating by Slovenian landslide researchers hosting the 4th World Landslide Forum in 2017 in Ljubljana, Slovenia (Alcántara-Ayala et al., 2017; Mikoš et al., 2017). This event may be understood as a landmark in Slovenian landslide research development. The impact of 2000 Stože Landslide on landslide disaster risk reduction policy in Slovenia is given in a companion paper (Mikoš, submitted).

\section{Acknowledgements}

The work on this manuscript was funded by the Slovenian Research Agency (ARRS) through research program P2-0180. The author would like to thank numerous colleagues for their enthusiastic cooperation and in-depth discussions in the field of landslide research from many aspects and with different perspectives that we had in these two decades after the 2000 Stože Landslide.

\section{Viri}

Allaby, M (Ed.) (2013). A Dictionary of Geology and Earth Sciences. 4th Ed., Oxford University Press, 660 p.

Armanini, A., Fraccarollo, L., Larcher, M. (2005). 142: Debris Flow. In: Anderson, M. G. (Ed.): Encyclopedia of Hydrological Sciences, Part 12. Open-Channel Flow, 2173-2185. https://doi.org/10.1002/0470848944.hsa149
Baroň, I., Supper, R., Winkler, E., Motschka, K., Ahl, A., Čarman, M., Kumelj, Š. (2013). Airborne geophysical survey of the catastrophic landslide at Stože, Log pod Mangrtom, as a test of an innovative approach for landslide mapping in steep alpine terrains. Natural Hazards and Earth System Sciences 13(10), 2543-2550. https://doi.org/10.5194/nhess-13-2543-2013

Bezak, N., Šraj, M., Mikoš, M. (2016). Copula-based IDF curves and empirical rainfall thresholds for flash floods and rainfall-induced landslides. Journal of Hydrology $\quad \mathbf{5 4 1}, \quad 272-284$. https://doi.org/10.1016/j.jhydrol.2016.02.058

Bezak, N., Šraj, M., Mikoš, M. (2017). Analysis of rainfall-triggered extreme landslide events in Slovenia in the last 25 years. In: Abolmasov, B., Marjanović, M., Đurić, U. (Eds.): Proceedings of the 2nd Regional Symposium on Landslides in the Adriatic-Balkan Region, RESYLAB, Belgrade 14-16 May 2015. Belgrade: University of Belgrade, Faculty of Mining and Geology, 203-208.

Bezak, N., Brilly, M., Šraj, M., Mikoš, M. (2018). Intensity-duration-frequency curves for rainfall-induced shallow landslides and debris flows using copula functions: TXT-tool 2.386-1.1. In: Sassa, K., Tiwari, B., Liu, K.-F., McSaveney, M., Strom, A., Setiawan, H. (Eds.): Landslide dynamics: ISDR-ICL landslide interactive teaching tools. Vol. 2, Testing, risk management and country practices. Berlin: Springer, 425-431. https://link.springer.com/chapter/10.1007/9783-319-57774-6 32

Bezak, N., Jemec Auflič, M., Mikoš, M. (2019a). Application of hydrological modelling for temporal prediction of rainfall-induced shallow landslides. Landslides $\quad \mathbf{1 6 ( 7 ) ,}$ 1273-1283. https://doi.org/10.1007/s10346-019-01169-9

Bezak, N., Sodnik, J., Mikoš, M. (2019b). Impact of a random sequence of debris flows on torrential fan formation. Geosciences $\quad \mathbf{9}, \quad 2 / 64, \quad 1-14$. https://doi.org/10.3390/geosciences9020064

Bezak, N., Jež, J., Sodnik, J., Jemec Auflič, M., Mikoš, M. (2020). An extreme May 2018 debris flood case study in northern Slovenia: analysis, modelling, and mitigation. Landslides 17(10), 2373-2383. https://doi.org/10.1007/s10346-019-01325-1

Brilly, M., Mikoš, M., Kobold, M. (2002). Catastrophe caused by debris flow in the village of Log pod Mangartom in autumn 2000. In: Deidda, R., Mugnai, R., Siccardi, F. (Eds.): Mediterranean storms: proceedings of the 3rd EGS Plinius conference held at Baja Sardinia, 
Italy, 1-3 October 2001. Roma: Consiglio Nazionale delle Ricerche, 367-370.

Brilly, M., Vidmar, A., Šraj, M., Mikoš, M., Kobold, M., Sušnik, M., Uhan, J. (2001). Hidrološki vzroki plazu Stože pod Mangartom (Hydrologic causes of the Stože Landslide below Mt. Mangart). In: Vodopivec, F. (Ed.): Raziskave s področja geodezije in geofizike - 2001: zbornik predavanj. Ljubljana: Fakulteta za gradbeništvo in geodezijo, Katedra za geodezijo, 39-54 (in Slovenian).

Caine, N. (1980) The Rainfall Intensity: Duration Control of Shallow Landslides and Debris Flows. $\begin{array}{llll}\text { Geografiska } & \text { Annaler } & \text { 62, } & \end{array}$ https://doi.org/10.2307/520449

Coussot, P. (1997). Mudflow Rheology and Dynamics, IAHR Monograph, Rotterdam, A. A. Balkema, 255 p.

Coussot, P., Meunier, M. (1996). Recognition, classification and mechanical description of debris flows. Earth-Science Reviews 40, 209-227. https://doi.org/10.1016/0012-8252(95)00065-8

Četina, M., Krzyk, M. (2003). Dvodimenzijsko modeliranje gibanja drobirskega toka $\mathrm{v}$ Logu pod Mangartom kot primer nenewtonske tekočine = TwoDimensional Modelling of Debris-Flow Movement in Log pod Mangartom as an Example of a Non-Newtonian Fluid. Strojniški vestnik = Journal of Mechanical Engineering 49(3), 161-172. Available at: http://www.dlib.si/details/URN:NBN:SI:doc-

\section{FKERQY0O}

Četina, M., Rajar, R., Hojnik, T., Zakrajšek, M., Krzyk, M. (2002). Modeliranje dinamike zemeljskega plazu Stože pod Mangartom (Modelling of Debris Flow at Log pod Mangartom). Ujma 16, 226-238. Available at: http://www.sos112.si/slo/tdocs/ujma/2002/u06.pdf (in Slovenian).

Četina, M., Rajar, R., Hojnik, T., Zakrajšek, M., Krzyk, M., Mikoš, M. (2006). Case Study: Numerical Simulations of Debris Flow below Stože, Slovenia. Journal of Hydraulic Engineering 132(2), 121-130. https://doi.org/10.1061/(ASCE)0733-

9429(2006)132:2(121)

ESA (2000). Landslide in Slovenia - 27.11.2000. The International Charter Space and Major Disasters. Available at:

https://disasterscharter.org/web/guest/activations/$\underline{\text { /article/landslide-in-sloven-8 }}$

Fan, X., Scaringi, G., Korup, O., West, A. J., van Westen, C. J., Tanyas, H., Hovius, N., Hales, T. C., Jibson, R. W., Allstadt, K. E., Zhang, L., Evans, S. G., Xu, C., Li, G.,
Oei, X., Xu, Q., Huang, R. (2019). Earthquake-Induced Chains of Geologic Hazards: Patterns, Mechanisms, and Impacts. Reviews of Geophysics 57(2), 421-503. https://doi.org/10.1029/2018RG000626

Fazarinc, R. (2002). Matematično modeliranje drobirskega toka v Logu pod Mangartom (Mathematical modelling of the debris flow in Log pod Mangartom). Unpublished MSc Thesis, University of Ljubljana, Faculty of Civil and Geodetic Engineering. (in Slovenian).

Fazarinc, R., Četina, M., Mikoš, M. (2002). Značilnosti drobirskih tokov ter tveganje in varovanje pred drobirskimi tokovi (Characteristics of debris flows and risks and protection against debris flows). Mišičev vodarski dan 2002, Maribor, Zbornik del, 84-91. Available at: http://www.mvd20.com/LETO2002/R13.pdf (in Slovenian).

Fazarinc, R., Majes, B., Mikoš, M. (2006). Using results of mathematical modeling of debris flows for optimization of a river channel form to convey debris flows and floods. In: Ferreira, R.M.L. (Ed.): River flow: proceedings of the International Conference on Fluvial Hydraulics, Lisbon, Portugal, 6-8 September 2006. London: Taylor \& Francis, 2137-2146.

Fidej, G., Mikoš, M., Rugani, T., Jež, J., Kumelj, Š., Diaci, J. (2015). Assessment of the protective function of forests against debris flows in a gorge of the Slovenian Alps. $\quad$ IForest $\quad \mathbf{8 / 1}, \quad 73-81$. https://doi.org/10.3832/ifor0994-007

Gams, I. (2001). Mangartski plaz v luči plazovne terminologije (Mangart Landslide in Light of Slide Terminology). Ujma 14-15, 452-453. Available at: http://www.sos112.si/slo/tdocs/ujma/2001/p14_1.pdf (in Slovenian).

Geografski terminološki slovar (2013). Založba ZRC SAZU, Ljubljana. 451 p. https://doi.org/10.3986/978961-254-470-6 (in Slovenian).

Geološki terminološki slovar (2006). Založba ZRC SAZU, Ljubljana. 331 p. https://doi.org/10.3986/9789610502913 (in Slovenian).

Gostinčar, M. (2001). Opazovanje potresne dejavnosti po sproženju gruščnatega toka (Seismic activity monitoring after the gravel flow). In: Vidrih, R. (Ed.): Potresi v letu 2000 (Earthquakes in 2000). Ljubljana, Environmental Agency of the Republic of Slovenia, 81-85. Available at: https://www.arso.gov.si/potresi/poro\%C4\%8Dila\%20in \%20publikacije/potresi\%20v\%20letu\%202000.pdf (in Slovenian). 
Hojnik, T. (2004). Dvodimenzijski matematični model drobirskih tokov na območju Koseča z oceno ogroženosti naselja Koseč zaradi njihovega delovanja (Twodimensional mathematical model of debris flows in the area of Koseč with a debris-flow risk assessment for the village of Koseč), 15. Mišičev vodarski dan 2004, Maribor, Zbornik del, 247-251. Available at: http://www.mvd20.com/LETO2004/R33.pdf (in Slovenian).

Hojnik, T., Četina, M., Krzyk, M., Rajar, R. (2001). Dvodimenzijski model drobirskega toka na območju Zgornjega in Spodnjega Loga (Two-dimensional model of debris flow in the area of Zgornji and Spodnji Log). 12. Mišičev vodarski dan 2001, Maribor, Zbornik del, 84-91. Available

at: http://www.mvd20.com/LETO2001/R13.pdf (in Slovenian).

Horvat, A. (2001). Hudourniški izbruh izpod Mangarta (Debris flow below Mangart). Ujma 14-15, 92-97. Available at: http://www.sos112.si/slo/tdocs/ujma/2001/p3_4.pdf (in Slovenian).

Hungr, O., Leroueil, S., Picarelli, L. (2014). The Varnes classification of landslide types, an update. Landslides 11, 167-194. https://doi.org/10.1007/s10346-013-0436y

Hutchinson, J.N. (1968). Mass movement. In: Fairbridge, R.W. (Ed.): Encyclopedia of Geomorphology, Reinhold, New York, 688-695.

Hutchinson, J.N. (1988). General report: Morphological and geotechnical parameters of landslides in relation to geology and hydrogeology. In: Bonnard, C. (Ed.): Proceedings of the 5th International Symposium on Landslides, Balkema, Rotterdam, Vol. 1, 3-36.

Jakob, M., Hungr, O. (2005). Debris-flow Hazards and Related Phenomena. Springer-Praxis Books in Geophysical Sciences, 739 p. https://doi.org/10.1007/b138657.

Jemec, M., Mikoš, M. (2008). Pobočni masni premiki na satelitskih posnetkih SPOT: Primer območja Železnikov po vodni ujmi septembra 2007 (Slope mass movements on SPOT satellite images: A case of the Železniki area (W Slovenia) after flash floods in September 2007). Geologija 51/2, 235-243. https://doi.org/10.5474/geologija.2008.024 (in Slovenian).

Jemec Auflič, M. (2012). Uporaba metode permanentnih sipalcev $\mathrm{v}$ geologiji kot podpora pri proučevanju plazljivih območij (Application of the permanent scatterers technique in geology as a support for the landslide prone areas investigation). $\mathrm{PhD}$ Thesis, Faculty of Natural Sciences and Engineering, University of Ljubljana, 197 p. (in Slovenian).

Jemec Auflič, M., Mikoš, M. (2009). Določevanje verjetnosti pojavljanja plazov na območju Železnikov iz satelitskih posnetkov SPOT po vodni ujmi 2007. In: Horvat, A. (Ed.): Razprave, poročila = Treatises, reports. 19. posvetovanje slovenskih geologov $=19$ th Meeting of Slovenian Geologists, Ljubljana, marec 2009. Ljubljana: Univerza v Ljubljani, Naravoslovnotehniška fakulteta, Oddelek za geologijo, Geološki zbornik, 20, 61-64. (in Slovenian).

Jemec Auflič, M., Jež, J., Popit, T., Košir, A., Maček, M., Logar, J., Petkovšek, A., Mikoš, M., Calligaris, C., Boccali, C., Zini, L., Reitner, J.M., Verbovšek, T. (2017). The variety of landslide forms in Slovenia and its immediate NW surroundings. Landslides 14, 1537-1546. https://doi.org/10.1007/s10346-017-0848-1

Jež, J., Mikoš, M., Trajanova, M., Kumelj, Š., Bavec, M. (2008). Vršaj Koroška Bela - Rezultat katastrofičnih pobočnih dogodkov (Koroška Bela alluvial fan - The result of the catastrophic slope events; (Karavanke Mountains, NW Slovenia)). Geologija 51(2), 219-227. https://doi.org/10.5474/geologija.2008.022 (in Slovenian).

Jurček, T. (2020). Laboratorijske meritve reologije naravnega drobirskega materiala (Laboratory analysis of natural debris material rheology). Master Thesis, University of Ljubljana, Faculty of Civil and Geodetic Engineering, 76 p. Available at: https://repozitorij.unilj.si/Dokument.php?id=134206 (in Slovenian).

Kaltak, S. (2018). Mathematical modeling of debris flows and formation of torrential fans. MSc Thesis, Faculty of Civil and Geodetic Engineering, University of Ljubljana, 95 p. Available at: https://repozitorij.unilj.si/Dokument.php?id=116663\&lang=slv (in Slovenian)

Kočevar, M., Ribičič, M. (2002). Geološke, hidrogeološke in geomehanske raziskave plazu Slano blato (Geological, hydrogeological and geomechanical investigation of the Slano blato landslide). Geologija 45, 427-432. https://doi.org/10.5474/geologija.2002.043

Komac, B. (2001). Geografski vidiki nesreče (Geographical Aspects of the Disaster in Log pod Komac, B., Ferk, M., Pipan, P., Tičar, J., Zorn, M. (2019). Natural Hazards in Slovenia. In: Perko, D., Ciglič, R., Zorn, M. (Eds.): The Geography of Slovenia, World Regional Geography Book Series, Springer 
Nature, Chapter 17, 259-277. Available at: https://link.springer.com/chapter/10.1007/978-3-030$\underline{14066-3 \quad 17}$

Komac, B. (2001). Geografski vidiki nesreče (Geographical Aspects of the Disaster in Log pod Mangartom). UJMA 14-15, 60-66. Available at: http://www.sos112.si/slo/tdocs/ujma/2001/p3_1.pdf (in Slovenian).

Komac, M., Bavec, M. (2007). Opazovanje vertikalne komponente recentnih premikov $\mathrm{v}$ Julijskih Alpah $\mathrm{s}$ PSInSAR metodo (Application of PSInSAR for observing the vertical component of the recent surface displacements in Julian Alps). Geologija 50/1, 97-110. https://doi.org/10.5474/geologija.2007.008

(in Slovenian).

Komac, B., Zorn, M. (2007). Pobočni procesi in človek (Slope Processes and Man). Ljubljana: Geografski inštitut Antona Melika, Geografija Slovenije 15, 220 p. https://doi.org/10.3986/9789612545307 (in Slovenian).

Komac, B., Zorn, M. (2008). The debris flow in Log pod Mangartom, NW Slovenia. WIT Transactions on Engineering Sciences 60, 125-133. https://doi.org/10.2495/DEB080131

Komac, M., Milanič, B., Jež, J., Bavec, M., Holley, R., Mahapatra, P., Hanssen, R., van der Marel, H., Fromberg, A. (2012). Opazovanje plazenja s kombinacijo metod radarske interferometrije in GPS (Observation of slope mass movement with the combination of radar interferometry methods and the GPS). UJMA 26, 175-182. Available at: http://www.sos112.si/slo/tdocs/ujma/2012/175.pdf (in Slovenian).

Komac, M., Holly, R., Mahapatra, P., Van der Marel, H., Bavec, M. (2015). Coupling of GPS/GNSS and radar interferometric data for a 3D surface displacement monitoring of landslides. Landslides 12, 241-257. https://doi.org/10.1007/s10346-014-0482-0

Lenart, S. (2004). Stože Landslide - A Case History. 5th International Conference on Case Histories in Geotechnical Engineering, Paper No. 2.10, 8 p. Available at:

https://scholarsmine.mst.edu/icchge/5icchge/session02/ $\underline{6}$

Lenart, S. (2006). Deformation characteristics of lacustrine carbonate silt in the Julian Alps. Soil Dynamics and Earthquake Engineering 26(2-4), 131-142. https://doi.org/10.1016/j.soildyn.2005.02.010
Lenart, S. (2008). The response of saturated soils to a dynamic load. Acta Geotechnica Slovenica 2008/1, 3749. Available at: http://fgserver6.fg.um.si/journalags/pdfs/AGS_2008-1_article_3.pdf

Lenart, S. (2011). The use of Dissipated Energy at Modeling of Cyclic Loaded Saturated Soils. In: Miura, T., Ikeda, Y. (Eds.) Earthquake Engineering: New Research, Nova Science Publishers, 295-321.

Lenart, S. (2016). Debris-flow events at Mt Mangart, Slovenia. Quarterly Journal of Engineering Geology and Hydrogeology $\quad \mathbf{4 9 ( 2 ) ,}$ 117-124. https://doi.org/10.1144/qjegh2015-072

Lenart, S., Fifer Bizjak, K. (2010). Particularities of Stože and Lokavec landslides - Special laboratory tests for landslides modeling. WSEAS Transactions on Environment and Development 7(5), 355-364. Available at: $\quad$ http://www.wseas.us/elibrary/transactions/environment/2010/89-538.pdf

Maček, M. (2006a). Sukcija zemljin (Soil suction). Diploma Thesis, University of Ljubljana, Faculty of Civil and Geodetic Engineering, 68 p. Available at: https://repozitorij.uni-lj.si/Dokument.php?id=84021 (in Slovenian).

Maček, M. (2006b). Suction - water content relationship for soils. In: Szavits-Nossan, V. (Ed.): Proceedings of the 17th European Young Geotechnical Engineers conference: Zagreb, Croatia, 20.-22. July 2006. Zagreb: Croatian Geotechnical Society. 293-300.

Maček, M. (2012). Vpliv matrične sukcije na pomike plazu Slano Blato (Influence of matric suction on the movements of Slano Blato landslide). PhD Thesis, University of Ljubljana, Faculty of Civil and Geodetic Engineering, 210 p. Available at: https://repozitorij.unilj.si/Dokument.php?id=97985 (in Slovenian).

Maček, M., Petkovšek, A. (2008). Merjenje zemljinske sukcije v slovenskih geotehničnih laboratorijih (Soil suction measurements in Slovenian geotechnical laboratories). In: Logar, J., Petkovšek, A. (Eds.): Razprave 5. posvetovanja slovenskih geotehnikov, Nova Gorica 2008. Ljubljana: Slovensko geotehniško društvo. 133-142. Available at: http://sloged.si/wpcontent/uploads/Razprave\%205.\%20posvetovanja/24.pdf (in Slovenian).

Maček, M., Majes, B., Petkovšek, A. (2012a). Gibanje vode v plazu Slano blato (Movement of water in Slano blato landslide). In: Pekovšek, A., Klopčič, J. (Eds.): Razprave. Ljubljana: Slovensko geotehniško društvo. 2012, 249-262 (in Slovenian). 
Maček, M., Mikoš, M., Petkovšek, A., Majes, B. (2012b). Influence of soil suction on stability of landslide = Uticaj sukcije tla na stabilnost klizišta. In: Sunarić, D., Jevremović, D. (Eds.): Zbornik radova XIV. simpozijuma iz inženjerske geologije i geotehnike sa međunarodnim učešćem, Beograd, 27. i 28. septembar, 2012. Beograd: Društvo geoloških inženjera i tehničara Srbije. 479-488.

Maček, M., Majes, B., Petkovšek, A. (2016). Lessons learned from 6 years of suction monitoring of the Slano blato landslide. Rivista Italiana di Geotecnica 5, 21-33.

Maček, M., Petkovšek, A., Arbanas, Ž., Mikoš, M. (2017a). Geotechnical aspects of landslides in flysch in Slovenia and Croatia. In: Abolmasov, B., Marjanović, M., Đurić, U. (Eds.): Proceedings of the 2nd Regional Symposium on Landslides in the Adriatic-Balkan Region, RESYLAB, Belgrade 14-16 May 2015. Belgrade: University of Belgrade, Faculty of Mining and Geology. 25-30.

Maček, M., Smolar, J., Petkovšek, A. (2017b). Influences of rheometer size and the grain size on rheological parameters of debris flow. In: Mikoš, M., Tiwari, B., Yin, Y., Sassa, K. (Eds.): Advancing Culture of Living With Landslides, Vol. 2, Advances in Landslide Science, 399 406. https://doi.org/10.1007/978-3-319-53498-5 46

Majes, B. (2001a). Analiza plazu in možnosti njegove sanacije (Analysis of Landslide and its Rehabilitation). Ujma 14-15, 80-91. Available at: http://www.sos112.si/slo/tdocs/ujma/2001/p3 3.pdf (in Slovenian).

Majes, B. (2001b). Plaz Stože, njegove posledice in možnosti sanacije. In: Svetličič, S. (Ed.): Zbornik referatov. Ljubljana: DRC, Družba za raziskave v cestni in prometni stroki Slovenije, 137-147 (in Slovenian).

Majes, B., Petkovšek, A. (2001). Kako zmanjšati ogroženost Loga pod Mangartom pred morebitnimi novimi drobirskimi tokovi (How to reduce new possible debris flows, which jeopardize Log pod Mangartom). In: Lopatič, J., Saje, F. (Eds.): 23. zborovanje gradbenih konstruktorjev Slovenije, Bled, 18.-19. oktober 2001. Zbornik. Ljubljana: Slovensko društvo gradbenih konstruktorjev, 9-20 (in Slovenian).

Majes, B., Petkovšek, A., Špacapan, I., Ločniškar, A. (2001). Klizište Stože pod Mangartom = Landslide Stože pod Mangartom. In: Mitrović, P. (Ed.): Zbornik radova. Beograd: Institut za puteve: Rudarsko-geološki fakultet Univerziteta u Beogradu, 622-629.

Majes, B., Beseničar, S. (2002). Zmanjšanje ogroženosti po plazu Stože (Reducing the Hazard after the Stože
Landslide). Ujma 16, 313-318. Available at: http://www.sos112.si/slo/tdocs/ujma/2002/u09.pdf (in Slovenian).

Majes, B., Petkovšek, A., Logar, J. (2002a). Primerjava materialnih lastnosti drobirskih tokov iz plazov Stože, Slano blato in Strug $=$ The comparison of material properties of debris flows from Stože, Slano blato and Strug landslides. Geologija 45(2), 457-463. https://doi.org/10.5474/geologija.2002.048 (in Slovenian).

Majes, B., Petkovšek, A., Logar, J. (2002b). Log pod Mangartom - eno leto kasneje. In: Žlender, B., Dolinar, B. (Eds.): 2. Šukljetovi dnevi, Maribor, 19. oktober 2001. Zbornik referatov. Ljubljana: Slovensko geotehniško društvo, 59-74. Available at: http://sloged.si/wpcontent/uploads/zborniki\%20sukljetovih\%20dnevov/2/1 -8.pdf (in Slovenian).

Majes, B., Petkovšek, A., Logar, J. (2002c). Landslide Stože pod Mangartom. In: Malabdi, M. (Ed.): Geotehnika kroz Eurocode 7, 3. Savjetovanje HUMTGI, Hvar 2-5. listopada 2002. Geotehnika kroz EUROCODE 7: priopćenja. Zagreb: Hrvatska udruga za mehaniku tla i geotehničko inženjerstvo, 67-78.

Majes, B., Petkovšek, A., Logar, J. (2002d). Landslide Stože - consequences and feasibility of corrective measures. Proceedings of the 12th Danube - European Conference, Passau, 235-238.

Majes, B. (2005). Izvajanje postopne sanacije velikih plazov v Sloveniji (Carrying out gradual repair of large landslides in Slovenia). In: Macuh, B. (Ed.): Zbornik referatov 6. Šukljetovega dneva. Ljubljana: Slovensko geotehniško društvo, 17-38 (in Slovenian). Available at: http://sloged.si/wp-

content/uploads/zborniki\%20sukljetovih\%20dnevov/6/2 .pdf

Meunier, M. (1991). Eléments d'hydraulique torrentielle (Elements of torrential hydraulics). Études du Cemagref, série montagne $\mathrm{n}^{\circ} 1$, Cemagref, France, 278 p. Available at: https://www.quae-open.com/extract/198 (in French).

Mikoš, M. (1995). Soodvisnost erozijskih pojavov v prostoru (Interdependence of Erosion Processes in Environment). Gozdarski vestnik 53, 342-351. Available at:

https://www.researchgate.net/publication/236898216_S oodvisnost_erozijskih_pojavov_v_prostoru_Interdepend ence of erosion_processes in environment

(in Slovenian).

Mikoš, M. (2000). Izrazje na področju erozijskih pojavov (Technical terms in the field of erosion processes). 
Gradbeni vestnik 49(5), 102-114. Available at: http://www.zveza-dgits.si/3714/pdf:1 (in Slovenian).

Mikoš, M. (2001). Značilnosti drobirskih tokov (Characteristics of Debris Flows). Ujma 14-15, 295-299. Available at: http://www.sos112.si/slo/tdocs/ujma/2001/p7_2.pdf (in Slovenian).

Mikoš, M. (submitted). After 2000 Stože Landslide Part II - Development in landslide disaster risk reduction policy in Slovenia. Acta hydrotechnica (submitted for review).

Mikoš, M., Bezak, N. (2021). Debris flow modelling using RAMMS model in the alpine environment with focus on the model parameters and main characteristics. Frontiers in Earth Science. https://doi.org/10.3389/feart.2020.605061

Mikoš, M., Fazarinc, R. (2000). Earthquake-induced erosion processes in two alpine valleys in Slovenia. Proc. of the Int. Symp. INTERPRAEVENT (Villach, Austria), Vol. 2, eds. F. Zollinger \& G. Fiebiger, 143-154.

Mikoš, M., Fazarinc, R. (2005). Natural erosion processes in the Koritnica River, W Slovenia, after the Stože debris flow. In: Proceedings of the XXXI IAHR Congress. Korean Water Resources Association. Seoul. 3757-3769.

Mikoš, M., Majes, B. (2008). Causes and Mitigation of Large Rainfall-Induced Landslides and Debris Flows in Last Years in Slovenia. In: Proceedings of the First World Landslide Forum: 18.-21. November 2008 United Nations University, Tokyo, Japan: Parallel Session Volume. Tokyo: Association for Disaster Prevention Research, 413-416.

Mikoš, M., Majes, B. (2010). Mitigation of large landslides and debris flows in Slovenia, Europe. In: Werner, E.D., Friedman, H.P. (Eds.): Landslides: causes, types and effects. New York: Nova Science Publishers, 105-131. Available at: http://drugg.fgg.uni-lj.si/3774/.

Mikoš, M., Kryžanowski, A. (2011). Debris-flow breakers as an unconventional dam type. In: Dams recent experiences on research, design, construction and service: international symposium, 17 - 18 November, 2011. Skopje: Macedonian committee on large dams. Vol. 1, 63-70. Available at: http://www.slocold.si/zbornik/Z_13.pdf

Mikoš, M., Štravs, L., Petkovšek, G., Brilly, M. (2002a). Prodna bilanca povodja reke Koritnice - 1. letna prodonosnost (Sediment budget of the Koritnica River Basin -1 . Yearly sediment transport rates). Gradbeni vestnik 51(11), 316-321. Available at: http://www.zveza-dgits.si/3549/pdf:1 (in Slovenian).

Mikoš, M., Štravs, L., Petkovšek, G., Brilly, M. (2002b). Prodna bilanca povodja reke Koritnice - 2. morfološke spremembe (Sediment budget of the Koritnica River Basin - 2. Morphological changes). Gradbeni vestnik 51(12), 316-321. Available at: http://www.zvezadgits.si/3558/pdf:1 (in Slovenian).

Mikoš, M., Petkovšek, G., Šraj, M., Brilly, M. (2002c). Analiza erozije tal v porečju Koritnice (Soil Erosion Analysis in the Koritnica River Catchment). Ujma 16, 319-325. Available at: http://www.sos112.si/slo/tdocs/ujma/2002/u09.pdf (in Slovenian).

Mikoš, M., Vidmar, A., Šraj, M., Kobold, M., Sušnik, M., Uhan, J., Pezdič, J., Brilly, M. (2002d). Hidrološke analize na plazu Stože pod Mangartom (Hydrologic Analyses of the Stože Landslide). Ujma 16, 326-334. Available http://www.sos112.si/slo/tdocs/ujma/2002/u09.pdf (in Slovenian).

Mikoš, M., Brilly, M., Ribičič, M. (2004a). Poplave in zemeljski plazovi v Sloveniji $=$ Floods and Landslides in Slovenia. Acta hydrotechnica 22/37, 113-133. Available at: $\quad$ https://actahydrotechnica.fgg.unilj.si/si/paper/a37mm.

Mikoš, M., Četina, M., Brilly, M. (2004b). Hydrologic conditions responsible for triggering the Stože landslide, Slovenia. Engineering Geology 73, 193-213. https://doi.org/10.1016/j.enggeo.2004.01.011

Mikoš, M., Rojnik, F., Fazarinc, R. (2004c). River engineering measures in an Alpine river after a major debris flow event. INTERPRAEVENT 2004, Riva del Garda, Italy, Vol. 4, 181-192. Available at: http://www.interpraevent.at/palm-

cms/upload_files/Publikationen/Tagungsbeitraege/2004 4_VIII-181.pdf

Mikoš, M., Vidmar, A., Brilly, M. (2005). Using a laser measurement system for monitoring morphological changes on the Strug rock fall, Slovenia. Natural Hazards and Earth System Science 5(1), 143-153. Available at: https://nhess.copernicus.org/articles/5/143/2005/nhess5-143-2005.pdf

Mikoš, M., Brilly, M., Fazarinc, R., Ribičič, M. (2006a). Strug landslide in W Slovenia: A complex multi-process phenomenon. Engineering Geology 81(1-3), 22-35. https://doi.org/10.1016/j.enggeo.2005.06.037 
Mikoš, M., Fazarinc, R., Ribičič, M. (2006b). Sediment production and delivery from recent large landslides and earthquake-induced rock falls in the Upper Soča River Valley, Slovenia. Engineering Geology 86/2-3, 198-210. https://doi.org/10.1016/j.enggeo.2006.02.015

Mikoš, M., Fazarinc, R., Majes, B., Rajar, R., Žagar, D., Krzyk, M., Hojnik, T., Četina, M. (2006c). Numerical simulation of debris flows triggered from the Strug rock fall source area, W Slovenia. Natural Hazards and Earth System Sciences 6, 261-270. https://doi.org/10.5194/nhess-6-261-2006

Mikoš, M., Fazarinc, R., Majes, B. (2007). Delineation of risk area in Log pod Mangartom due to debris flows from the Stože Landslide. Acta geographica Slovenica 47-2, 171-198. https://doi.org/10.3986/AGS47202

Mikoš, M., Petkovšek, A., Majes, B. (2009). Mechanisms of landslides in over-consolidated clays and flysch. Landslides 6, 367-371. https://doi.org/10.1007/s10346-009-0171-6

Mikoš, M., Jemec Auflič, M., Ribičič, M., Čarman, M., Komac, M. (2013). Earthquake-induced Landslides in Slovenia: Historical Evidence and Present Analyses. In: Ugai, K., Yagi, H., Wakai, A. (Eds.). Earthquakeinduced Landslides: Proceedings of the International Symposium on Earthquake-induced Landslides, Kiryu, Japan, 2012. Springer Verlag, 225-233. https://doi.org/10.1007/978-3-642-32238-9_23

Mikoš, M., Sodnik, J., Petkovšek, A., Maček, M., Majes, B. (2014). WCoE: Mechanisms of landslides in overconsolidated clays and flysch and IPL-151 project: Soil matrix suction in active landslides in flysch - the Slano Blato landslide case. In: Sassa, K., Canuti, P., Yin, Y. (Eds.): Landslide science for a safer geoenvironment. Vol. 1, The international programme on landslides (IPL). Cham: Springer International Publishing Switzerland. 143-148.

Mikoš, M. Yin, Y., Sassa, K. (2017). The Fourth World Landslide Forum, Ljubljana, 2017. Landslides 14, 1843 1854. https://doi.org/10.1007/s10346-017-0889-5

Novak, A., Popit, T., Šmuc, A. (2018). Sedimentological and geomorphological characteristics of Quaternary deposits in the Planica-Tamar Valley in the Julian Alps (NW Slovenia). Journal of Maps 14(2), 382-391. https://doi.org/10.1080/17445647.2018.1480975

Novak, A., Popit, T., Levanič, T., Šmuc, A., Kaczky, R.J. (2020). Debris flooding magnitude estimation based on relation between dendrogeomorphological and meteorological records. Geomorphology 367, 107303. https://doi.org/10.1016/j.geomorph.2020.107303
Oštir, K., Veljanovski, T., Podobnikar, T., Stančič, Z. (2003). Application of satellite remote sensing in natural hazard management: the Mount Mangart landslide case study. International Journal of Remote Sensing 24(20), 3983-4002.

https://doi.org/10.1080/0143116031000103826

Oven, D., Levanič, T., Jež, J., Kobal, M. (2019). Reconstruction of Landslide Activity Using Dendrogeomorphological Analysis in the Karavanke Mountains in NW Slovenia. Forests 10(11), 1009. https://doi.org/10.3390/f10111009

Peranić, J., Arbanas, Ž., Cuomo, S., Maček, M. (2018). Soil-water characteristic curve of residual soil from a flysch rock mass. Geofluids 2018, 6297819, 1-15. https://doi.org/10.1155/2018/6297819

Peternel, T., Kumelj, Š., Oštir, K., Komac, M. (2017). Monitoring the Potoška Planina landslide (NW Slovenia) using UAV photogrammetry and tachymetric measurements. Landslides 14(1), 395-406. https://doi.org/10.1007/s10346-016-0759-6

Petkovšek, A. (2001a). Geološko geotehnične raziskave plazu (Geological-geotechnical Investigations of the Stože Landslide). Ujma 14-15, 109-117. Available at: http://www.sos112.si/slo/tdocs/ujma/2001/p3 7.pdf (in Slovenian).

Petkovšek, B. (2001b). Geološke značilnosti plazu (Geological Characteristics of the Stože Landslide). Ujma 14-15, 98-101. Available at: http://www.sos112.si/slo/tdocs/ujma/2001/p3 5.pdf (in Slovenian).

Petkovšek, A. (2002). Pomen geotehničnih raziskav pri preučevanju drobirskih tokov in prve slovenske izkušnje (The importance of geotechnical research in studying debris flows and the first Slovenian experiences). Gradbeni vestnik 51(12), 346-361. Available at: http://www.zveza-dgits.si/3558/pdf:1 (in Slovenian).

Petkovšek, A. (2006). Vpliv matrične sukcije na trdnostno deformacijske lastnosti zemljin (Influence of matric suction on strength and deformability characteristics of soils). PhD Thesis, University of Ljubljana, Faculty of Civil and Geodetic Engineering, 274 p. (in Slovenian).

Petkovšek, A. (2008). Zemljinska sukcija: nekaj primerov uporabe $\mathrm{v}$ geotehniki (Soil suction: Some examples of its application in geotechnical engineering). In: Logar, J., Petkovšek, A. (Eds.): Razprave 5. posvetovanja slovenskih geotehnikov, Nova Gorica 2008. Ljubljana: Slovensko geotehniško društvo. 283292. Available at: http://sloged.si/wp- 
content/uploads/Razprave\%205.\%20posvetovanja/44.pdf (in Slovenian).

Petkovšek, A., Maček, M., Majes, B. (2009a). Soil matrix suction: some examples of its application in geotechnical engineering in Slovenia. In: Izvori rizika u geotehničkim zahvatima: 5. savjetovanje, Osijek, 20-21. svibnja. Osijek: Hrvatsko geotehničko društvo: Građevinski fakultet Sveučilišta Josipa Jurija Strossmayerja. 9p.

Petkovšek, A., Maček, M., Kočevar, M., Benko, I., Majes, N. (2009b). Soil matric suction as an indicator of the mud flow occurrence. In: Hamza, M. (Ed.): Proceedings of the 17th International Conference on Soil Mechanics and Geotechnical Engineering: 5-9 October 2009, Alexandria, Egypt. Amsterdam: IOS Press. vol. 3, 1855-1860.

Petkovšek, A., Fazarinc, R., Kočevar, M., Maček, M., Majes, B., Mikoš, M. (2011). The Stogovce landslide in SW Slovenia triggered during the September 2010 extreme rainfall event. Landslides 8, 499-506. https://doi.org/10.1007/s10346-011-0270-Z

Petrica, R., Špacapan, I. (2001). Landslide Stože Geological-geotechnical Investigation: Engineeringgeological map, ZRMK, Ljubljana, (in Slovenian).

Rajar, R. (1978). Mathematical Simulation of DamBreak Flow. Journal of the Hydraulics Division 104(7), 1011-1026.

Rajar, R. (1980). Mathematical Models for Simulation of Flood Waves, of Dam-Break Waves and of Snow Avalanches. INTERPRAEVENT Congress 1980, Bad Ischl, Band 2, 111-119. Available at: http://www.interpraevent.at/palmcms/upload_files/Publikationen/Tagungsbeitraege/1980 2_111.pdf

Rajar, R. (1982). Mathematical simulation of snow avalanche dynamics. In: Gosar, P., Šuklje, L. (Eds.): Anton Kuhelj Memorial Volume, Slovenian Academy of Arts and Science, Ljubljana, 303-320.

Rajar, R., Četina, M., Zakrajšek, M., Krzyk, M., Hojnik, T. (2001). Enodimenzijski model drobirskega toka na območju Zgornjega in Spodnjega Loga. Mišičev vodarski dan, Maribor, Zbornik del, 92-101. Available at: http://www.mvd20.com/LETO2001/R14.pdf (in Slovenian).

Ranfl, I. (2010). Razvejana struga Soče v Bovški kotlini (Brading river Soča in the Bovec basin). Diploma Thesis Nr. 3115, University of Ljubljana, Faculty of Civil and Geodetic Engineering, 96 p. Available at: http://drugg.fgg.uni-lj.si/624/ (in Slovenian).
Ribičič, M. (2001). Značilnosti drobirskega toka Stože pod Mangartom (Debris Flow at Log pod Mangartom). Ujma 14-15, 102-108. Available at: http://www.sos112.si/slo/tdocs/ujma/2001/p3 6.pdf (in Slovenian).

Ribičič, M. (2002). Zemeljski plazovi, usadi in podori (Landslides, slumps, and rockfalls). In: Ušeničnik, B. (Ed.): Nesreče in varstvo pred njimi. Ljubljana: Uprava RS za zaščito in reševanje Ministrstva za obrambo, 260$266 . \quad$ Available at: http://www.sos112.si/slo/tdocs/naravne_nesrece.pdf (in Slovenian)

Ribičič, M., Vidrih, R. (2001). Gruščnati tok in potresna dejavnost $\mathrm{v}$ Logu pod Mangartom (Gravel flow and seisimic activity in Log pod Mangartom). In: Vidrih, R. (Ed.): Potresi v letu 2000 (Earthquakes in 2000). Ljubljana, Environmental Agency of the Republic of Slovenia, 29-80 (in Slovenian) Available at: https://www.arso.gov.si/potresi/poro\%C4\%8Dila\%20in \%20publikacije/potresi\%20v\%20letu\%202000.pdf

Rosi, A., Peternel, T., Jemec Auflič, M., Komac, M., Segoni, S., Casagli, N. (2016). Rainfall thresholds for rainfall-induced landslides in Slovenia. Landslides 13(6), 1571-1577. https://doi.org/10.1007/s10346-016$\underline{0733-3}$

Sassa, K., Nagai, O., Solidum, R., Yamazaki, Y., Ohta, H. (2010). An integrated model simulating the initiation and motion of earthquake and rain induced rapid landslides and its application to the 2006 Leyte landslide. $\quad$ Landslides $\quad 7(3), \quad 219-236$. https://doi.org/10.1007/s10346-010-0230-Z

Skaberne, D. (2001). Prispevek k slovenskemu izrazoslovju za pobočna premikanja (Contribution to the Slovene Terminology of Slope Movements). Ujma 1415, 454-458. Available at: http://www.sos112.si/slo/tdocs/ujma/2001/p14 2.pdf (in Slovenian).

Skaberne, D. (2002). Predlog slovenskega izrazoslovja pobočnih premikanj - pobočnega transporta (Proposal of the Slovene terminology on slope movements - slope transport). Geologija 44(1), 89-100. Available at: https://doi.org/10.5474/geologija.2001.006 (in Slovenian).

Sodnik, J. (2017). Ocenjevanje nevarnosti zaradi delovanja drobirskih tokov na hudourniških vršajih (Debris flow hazard assessment on torrential fans). $\mathrm{PhD}$ Thesis, University of Ljubljana, Faculty of Civil and Geodetic Engineering, 200 p. Available at: 
https://repozitorij.uni-lj.si/Dokument.php?id=108683 (in Slovenian).

Sodnik, J., Mikoš, M. (2006a). Estimation of magnitudes of debris flows in selected torrential watersheds in Slovenia = Ocena magnitud drobirskih tokov v izbranih hudourniških območjih v Sloveniji. Acta geographica Slovenica $\quad 46(1), \quad 93-123$. https://doi.org/10.3986/AGS46104

Sodnik, J., Mikoš, M. (2006b). Ocenjevanje magnitud drobirskih tokov (Debris-flow magnitude assessment). In: Kozmus Trajkovski, K., Kuhar, M. (Eds.): Raziskave $s$ področja geodezije in geofizike 2005: zbornik predavanj. Ljubljana: Univerza v Ljubljani, Fakulteta za gradbeništvo in geodezijo, 75-87. Available at: http://fgg-web.fgg.uni-

1j.si/SUGG/referati/2006/SZGG2006_Sodnik_Mikos.pd f (in Slovenian).

Sodnik, J., Mikoš, M. (2010). Modeling of a debris flow from the Hrenovec torrential watershed above the village of Kropa. Acta geographica Slovenica 50-1, 59-84. https://doi.org/10.3986/AGS50103

Sodnik, J., Mikoš, M. (2018). Two-dimensional debrisflow modelling and topographic data: TXT-tool 3.3861.1. In: Sassa, K., Tiwari, B., Liu, K.-F., McSaveney, M., Strom, A., Setiawan, H. (Eds.): Landslide dynamics: ISDR-ICL landslide interactive teaching tools. Vol. 2, Testing, risk management and country practices. Berlin: Springer, 235-250. https://doi.org/10.1007/978-3-31957777-7 11

Sodnik, J., Četina, M., Mikoš, M. (2009a). Vpliv reoloških lastnosti pri dvodimenzijskem modeliranju drobirskih tokov. In: Boltežar, M., Slavič, J (Eds.): Zbornik del. Kuhljevi dnevi, 24. September 2009, Cerklje na Gorenjskem. Ljubljana: Slovensko društvo za mehaniko, 148-155. Available at: http://www.drustvozamehaniko.si/zbornik/ZbornikKD2 009.pdf (in Slovenian).

Sodnik, J., Kumelj, Š., Peternel. T., Jež, J., Maček, M. (2017). Identification of Landslides as Debris Flow Sources Using a Multi-model Approach Based on a Field Survey - Koroška Bela, Slovenia, In: Mikoš, M., Tiwari, B., Yin, Y., Sassa, K. (Eds.): Advancing Culture of Living with Landslides, Vol. 2 - Advances in Landslide Science, 1119-1126. https://doi.org/10.1007/978-3-319$\underline{53498-5 \quad 127}$

Sodnik, J., Maček, M., Mikoš, M. (2018a). Stože landslide triggering simulation using LS-Rapid simulation model. In: Jemec Auflič, M., Mikoš, M., Verbovšek, T. (Eds.): Advances in Landslide Research.
Proceedings of the 3rd Regional Symposium on Landslides in the Adriatic-Balkan Region, 11-13 October 2017, Ljubljana. Geological Survey of Slovenia. 107112. Available at: https://www.geozs.si/PDF/Monografije/Advances_landslide_research.pd $\underline{\mathrm{f}}$

Sodnik, J., Maček, M., Mikoš, M. (2018b). Estimating Landslide Volumes Using LS-Rapid Model - The 2000 Stože Landslide in NW Slovenia. INTERPRAEVENT 2018, Toyama, Japan, 32-41. Available at: http://www.interpraevent.at/palm-

cms/upload_files/Publikationen/Tagungsbeitraege/2018 1_32.pdf

Sodnik, J., Petje, U., Mikoš, M. (2009b). Topografija površja in modeliranje gibanja drobirskih tokov $=$ Terrain topography and debris-flow modelling. Geodetski vestnik 53(2), 291-304 \& 305-318. Available at: http://www.geodetski-vestnik.com/53/2/gv53-2_291-

304.pdf \& $\quad$ http://www.geodetskivestnik.com/53/2/gv53-2 305-318.pdf.

Sodnik, J., Petje, U., Četina, M., Mikoš, M. (2010). On how terrain topography and rheological properties influence modeling of debris-flow run-out distances Case study of the Sava dolinka Valley, NW Slovenia. INTERPRAEVENT 2010, 283-292. Available at: http://www.interpraevent.at/palm-

cms/upload files/Publikationen/Tagungsbeitraege/2010 283.pdf

Sodnik, J., Podobnikar, T., Mikoš, M. (2012a). Using LiDAR data for debris flow modelling. INTERPRAEVENT 2012, Vol. 1, 573-583. Available at: $\quad$ http://www.interpraevent.at/palmcms/upload_files/Publikationen/Tagungsbeitraege/2012 1_573.pdf

Sodnik, J., Vrečko, A., Podobnikar, T., Mikoš, M. (2012b). Digitalni modeli reliefa in matematično modeliranje drobirskih tokov (Digital terrain models and mathematical modelling of debris flows). Geodetski vestnik $\quad \mathbf{5 6 ( 4 )}, \quad 826-837$. https://doi.org/10.15292/geodetski-vestnik.2012.04.826837 (in Slovenian).

Sodnik, J., Podobnikar, T., Petje, U., Mikoš, M. (2013). Topographic Data and Numerical Debris-Flow Modeling. In: Margottini, C., Canuti, P., Sassa, K. (Eds.): Landslide Science and Practice. Springer, Berlin, Heidelberg, 573-578. https://doi.org/10.1007/978-3-642-31325-7 75

Stiny, J. (1910). Die Muren. Verlag der Wagner'schen Universitätsbuchahndlung, Innsbruck. 
Šegina, E., Peternel, T., Urbančič, T., Realini, E., Zupan, M., Jež, J., Caldera, S., Gatti, A., Tagliaferro, G., Consoli, A., Reyes González, J., Jemec Auflič, M. (2020). Monitoring Surface Displacement of a DeepSeated Landslide by a Low-Cost and near Real-Time GNSS System. Remote sensing 12(20), 3375. https://doi.org/10.3390/rs12203375

Šmuc, A., Janecka, K., Lempa, M., Kaczka, R.J. (2015). The spatio-temporal dynamics of the Ciprnik complex landslide, Tamar Valley, Julian Alps, Slovenia. Studia Geomorphologica Carpatho-Balcanica 49, 35-54. https://doi.org/10.1515/sgcb-2015-0008

Takahashi, T. (1981). Debris flow. Annual Review of Fluid Mechanics 13, 57-77.

Takahashi, T. (1991). Debris Flow. IAHR Monograph, Rotterdam, A.A. Balkema, 165 p.

Takahashi, T. (2014). Debris Flow - Mechanics, Prediction and Countermeasures, 2nd Ed., Boca Raton, CRC Press, 540 p.

Varnes, D. J. (1978). Slope movement types and processes. In: Schuster, R. L., Krizek, R. J. (Eds.): Landslides, analysis and control. Special report 176, Transportation research board, National Academy of Sciences, Washington, DC., 11-33.

Wan, Z., Wang, Z. (1994). Hyperconcentrated Flow. IAHR Monograph, Rotterdam: A. A. Balkema, 300 p.

Zlodej, I. (2001). Plaz, ki je spremenil goro: leto dni po katastrofi $\mathrm{v}$ Logu pod Mangartom (Landslide that changed the mountain: one year after the catastrophe in Log pod Mangartom). Planinski vestnik 101(11), 468470. Available at: https://www.dlib.si/details/URN:NBN:SI:DOC932G0GC0 (in Slovenian).

Zorn, M., Komac, B. (2002). Pobočni procesi in drobirski tok v Logu pod Mangartom (Slope processes and the debris flow in Log pod Mangartom). Geografski vestnik 74(1), 9-23. Available at: http://zgs.zrcsazu.si/Portals/8/Geografski_vestnik/gv74-1zornkomac.pdf (in Slovenian).

Zorn, M., Komac, B. (2004). Recent mass movements in Slovenia. In: Adamič Orožen, M. (Ed.): Slovenia: a Geographical Overview, Ljubljana: Association of the Geographical Societies of Slovenia, Chapter 14, 73-80. Available at: http://zgs.zrcsazu.si/Portals/8/Slo_Geo_Over/14.pdf

Zorn, M., Komac, B. (2008). Zemeljski plazovi v Sloveniji (Landslides in Slovenia). Ljubljana: Založba
ZRC SAZU, Georitem 8, 159 p. https://doi.org/10.3986/9789612545505 (in Slovenian).

Zorn, M., Natek, K., Komac, B. (2006). Mass movements and flash-floods in Slovene Alps and surrounding mountains. Studia Geomorphologica CarpathoBalcanica XL, 127-145. https://www.igipz.pan.pl/tl_files/igipz/ZGiHGiW/sgcb/s gcb_40/sgcb_40_09.pdf

Zupančič, P., Cecić, I., Gosar, A., Placer, L., Poljak, M., Živčić, M. (2001). The earthquake of 12 April 1998 in the Krn Mountains (Upper Soča valley, Slovenia) and its seismotectonic characteristics. Geologija 44/1, 169-192, https://doi.org/10.5474/geologija.2001.012

ZV-1 (2002). Zakon o vodah (Water Act). Official Gazzette of the Republic of Slovenia 67, 7648-7680. Available at: $\quad$ https://www.uradnilist.si/_pdf/2002/Ur/u2002067.pdf (in Slovenian).

ZV-1-NPB8 (2020). Zakon o vodah (ZV-1) - neuradno prečiščeno besedilo št. 8 (Water Act - unofficial consolidated version Nr. 8). Available at: http://pisrs.si/Pis.web/pregledPredpisa?id=ZAKO1244 (in Slovenian) (28. 9. 2020).

Žibret, G., Komac, M., Jemec, M. (2012). PSInSAR displacements related to soil creep and rainfall intensities in the Alpine foreland of western Slovenia. Geomorphology 175-176, 104-114. https://doi.org/10.1016/j.geomorph.2012.07.002

Žlender, B., Lenart, S. (2005). Cyclic liquefaction potential of lacustrine carbonate silt from Julian Alps. Acta geotechnica Slovenica 2005/1, 23-31. Available at: http://fgserver3.fg.um.si/journal-ags/pdfs/AGS 20051 article 2.pdf 